\title{
İç Mekânda Biyofilik Tasarım ve Uygulama Alanı Olarak Bir Sağlık Yapısı: Memorial Bahçelievler Hastanesi
}

\author{
Muteber ERBAY ${ }^{1}$
}

Öz

Doğanın içinde yaşayan insanın barınaklarını inşa etmesiyle başlayan mimarlık, zaman içinde doğa ile insan arasında bir bariyer oluşturmaya başlamıştır. Doğadan esinlenilen, doğa ile iç içe üretilen yapılar, malzemenin, yapım tekniklerinin ve teknolojinin gelişmesi ile öncelikle coğrafyaya bağlı, zaman içinde de evrensel mimari yapılara dönüşmüştür. Ancak modern mimari ile birbirine benzer biçimlerle yaygınlaşan modern yapılarla beraber, insanın doğa ile ilişkisi zayıflamıştır. Bu bağın güçlendirilmesine yönelik birçok tasarım anlayışı bulunmaktadır. Biyofilik tasarım da bu tasarım anlayışlarından biridir. Asında insan-doğa-mekân ilişkisine bakıldığında biyofilik tasarımın kökenlerinin eskiye dayalı olduğu söylenebilir. Çünkü insanın içsel dünyasının derinliklerinde doğa ile kurduğu bağlantı öyle güçlüdür ki yapılı çevre içinde bunu bireysel olarak yansıtmaktadır. Biyofilik tasarım anlayışı bu bireysel çabanın tüm mekânda bir bütün olarak ele alınması, doğa ile mekân ilişkisinin bir dizi tasarım araçları ile değil, insan deneyimi üzerinden kurulması gerektiğini savunmaktadır. Bu çalışmada doğa ile mekân bağını kurmaya çalışan tasarım anlayışlarından biri olan biyofilik tasarım deneyimlerinin/ilkelerinin iç mekânda uygulama alanı olarak bir sağlık yapısı olan Memorial Bahçelievler Hastanesi analiz edilmektedir. Yöntem olarak analizlerde Browning, Ryan ve Clancy'in tanımladığı 14 biyofilik tasarım deneyimleri/ilkeleri esas alınmıştır. Sonuçlar bölümünde bu deneyimlerin/ilkelerin hastane yapısındaki tasarımlarla örtüşüp örtüşmediği ve biyofilik tasarımının uygulanabilirliği tartışılmaktadır.

Anahtar Kelimeler: Biyofilik Tasarım, İç Mekân ve Biyofilik Tasarım, Sağlık Yapısı ve Biyofilik Tasarım, Doğa Temelli Tasarım.

\section{A Healthcare Structure as A Biophilic Design and Application Area in The Interior: Memorial Bahçelievler Hospital}

\begin{abstract}
\footnotetext{
${ }^{1}$ Karadeniz Teknik Üniversitesi, Mimarlık Fakültesi, İç Mimarlık Bölümü, 61080, Trabzon

*ilgili yazar/Corresponding author: merbay@ktu.edu.tr

Gönderim Tarihi / Received Date: 27.04.2021

Kabul Tarihi / Accepted Date: 04.08.2021
}

Architecture started with the construction of shelters by people living in touch with nature, and over time created a barrier between nature and humans. With the development of materials, construction techniques, and technology, constructions inspired by nature and produced in touch with nature were transformed into universal architectural structures primarily dependent on geography and over time. However, human's relationship with nature has weakened with modern architecture and modern buildings that have become widespread with similar forms. Many design concepts are intended to strengthen this bond. Biophilic design is one of these design approaches. Indeed, considering the human-nature-space relationship, it can be said that the origins of biophilic design go back to ancient times. Because, in the depths of his inner world, the connection that human establishes with nature is so strong that it reflects this 
individually in the built environment. The biophilic design approach argues that handling this individual effort as a whole in the whole space should be based on human experience, and the relationship between nature and space should not be established with a series of design tools. Memorial Bahçelievler Hospital, which is a healthcare structure as an indoor application area of biophilic design experiences/principles, which is one of the design approaches that try to establish the connection between nature and space, is analyzed in this study. The 14 biophilic design experiences/principles defined by Browning, Ryan, and Clancy were used as a method in the analyzes. In the conclusions section, whether these experiences/principles overlap with hospital-built designs and the applicability of biophilic design are discussed.

Keywords: Biophilic Design, Interior and Biophilic Design, Health Structure and Biophilic Design, Nature-Based Design.

\section{Biyofilik Tasarım ve İç Mekân İle İlişkisi}

Biyofili kelimesi ilk kez 1964 yılında Amerikalı sosyolog Erich Fromm tarafından nekrofili $^{2}$ tanımına karşıtıı olarak kullanılmış (2005, s. 40), insana ve doğaya duyulan sevgi, bağımsızlık ve özgürlük olarak da tanımlanmıştır (2005, s.101). Bu tanımdan yirmi yıl sonra 1984 'te biyolog Edward O. Wilson (2003, s. 139) "Biyofili" hipotezini ortaya atmış, insan benliği ve diğer yaşayan sistemler arasında içgüdüsel bir bağ olduğunu öne sürmüştür. Birbirini destekleyen her iki bakış açısı da insanın doğuştan doğa ile beraber yaşama isteğine vurgu yapmaktadır. Biyofili hipotezinin popüler olmasını sağlayan önemli kaynaklardan birisi ise Kellert ve Wilson'un (1993) editörlüğünde yayınlanan "The Biophilia Hypothesis" isimli kitaptır.

Aslında mimari ile doğa ilişkisi tarih boyunca bilinçli ya da bilinçsiz bir şekilde kurulmuştur. Eski yerleşim ve yapılara bakıldığında doğa ile yapı ilişkisi her zaman güçlüdür. Çünkü mimarlık yerel kültürden ve malzemeden beslenerek gelişmiştir. Ancak modern mimari, küreselleşmenin etkisi ile mimarlığın geleneksel yapım sistemlerinden uzaklaşarak evrensel bir dil kazanmıştır. Dünyanın birçok büyük kentlerinde cam, çelik ve betonarmeden oluşan benzer yapı stokları yaygınlaşmıştır. Bütün bunlara ek olarak 19. yüzyılda sanayileşme ile artan kentleşmenin yanında tarım teknolojileri de gelişmiştir. Doğal çevre içinde insan eliyle düzenlenen peyzaj ve mimari sonucu bir takım ekolojik sorunlar da ortaya çıkmıştır. 20. yüzyıla girerken doğa ile insan arasında yaşanan bu gerilimin farkına varılmasıyla, bilimin öncülüğünde çevre sorunlarının ve ekosistemin düzeltilmesi için çalışmalara başlamıştır (Kellert 2006; Krčmářová, 2009). Özellikle doğadan uzaklaştıkça yapay çevrenin insan üzerinde yarattığı stres ve baskı, iş verimliliğini ve yaşam kalitesini de etkilemiştir. Bu konuda yapılan araştırmalar öfke ve saldırganlığın doğal ortamlarda azaldığı, kentsel ortamlarda ise arttığı yönündedir (Hartig ve diğ., 2003; Pranita ve Hejiib, 2019).

Bu noktadan hareketle modern yaşamın bir gerekliliği olarak günlük hayatımızın önemli bir bölümünü geçirdiğimiz yer yapılı çevre olduğundan, mimarinin ve iç mimarinin insanların fiziksel ve zihinsel sağlığı üzerindeki etkisi yadsınamaz. Yapılı çevre ile doğanın ilişkisini kurmaya yönelik organik mimari, yeşil tasarım, ekolojik tasarım, biyomimikri, rejeneratif tasarım gibi doğa temelli bir çok tasarım anlayışı bulunmaktadır (Şenozan, 2018, s. 11). Biyofilik tasarım da Kellert (2006) tarafından gündeme getirilen, diğer doğa temelli tasarım yaklaşımlarından farklı olarak doğa sevgisini bir bilinç düzeyinde tasarıma yansıtmayı amaçlayan bir yaklaşımdır.

\footnotetext{
${ }^{2}$ Nekrofili, necro (ölü) kelimesinden türetilmiş bir tür cinsel yönelim bozukluğudur. https://tr.wikipedia.org/wiki/Nekrofili
} 
Biyofilik tasarım, modern yapılı çevrede doğayla ilişki kurma intiyacı üzerine temellendirilmiştir. Ancak bu ilişki doğanın yapı içinde kullanılması şeklinde algılanmamalıdır. Biyofilik tasarımın uygulandığı ya da test edildiği birçok çalışma bulunmaktadır. Örneğin sürdürülebilir yapılarda (Leakas, 2008), konutlarda (Hudson, 2013), kafelerde (Çorakçı, 2016), üniversite binalarında (Mustafa ve Yaseen, 2019), ofislerde (Gray, 2018), hastane yapılarında (Akrami, 2017; Şenozan, 2018) yapılan çalışmalar biyofilik tasarımın mimarideki karşılığını çevre, yapı ve iç mekân düzeyinde sorgulamaktadırlar.

Biyofilik tasarımın uygulanmasına yönelik, mekân içindeki deneyimleri ve özellikleri konusunda temel alınan birkaç çalışma bulunmaktadır. Bunlardan ilki Kellert'e (2008) ait çalışmadır. Oldukça ayrıntılı hazırlanan bu çalışmada, 6 başlık altında toplam 72 özellik tanımlamaktadır. Temelde çevresel ve mekânsal özellikler üzerine yoğunlaşan Kellert ve Calabrese $(2015$, s.10) bu sınılandırmanın çerçevesini daha da özelleştirerek 24 deneyimi 3 ana başlık altına toplamıştır (Şekil 1). Bu sınıflandırmada ana başııklar; doğanın doğrudan deneyimlenmesi, doğanın dolaylı deneyimlenmesi ve mekânın ve yerin deneyimlenmesidir.

\begin{tabular}{|c|c|c|c|c|c|c|c|c|c|c|c|c|c|c|c|c|c|c|c|c|c|c|c|}
\hline \multicolumn{8}{|c|}{$\begin{array}{l}\text { Doğanın Doğrudan } \\
\text { Deneyimlenmesi }\end{array}$} & \multicolumn{10}{|c|}{ Doğanın Dolaylı Deneyimlenmesi } & \multicolumn{6}{|c|}{$\begin{array}{l}\text { Mekânın ve Yerin } \\
\text { Deneyimlenmesi }\end{array}$} \\
\hline$\frac{\stackrel{x}{w_{n}}}{\check{C}}$ & \begin{tabular}{|l}
$\frac{\pi}{2}$ \\
$\mathbb{T}$ \\
$I$ \\
$\dot{N}$
\end{tabular} & $\begin{array}{l}\bar{\omega} \\
\text { ले }\end{array}$ & $\begin{array}{l}\text { 訔 } \\
\dot{+}\end{array}$ & 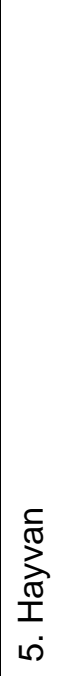 & $\begin{array}{l}\frac{. \underline{\underline{E}}}{\underline{\underline{\underline{I}}}} \\
\dot{0}\end{array}$ & 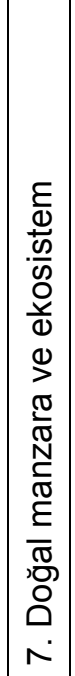 & 赵 & 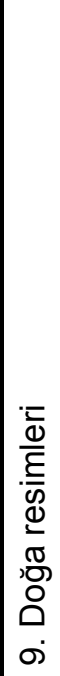 & 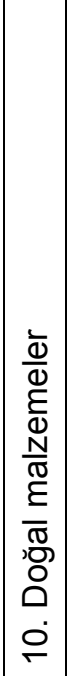 & 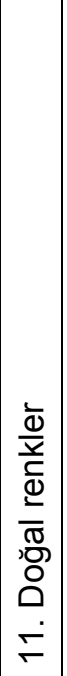 & 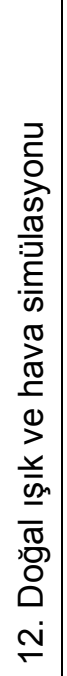 & 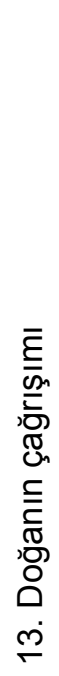 & 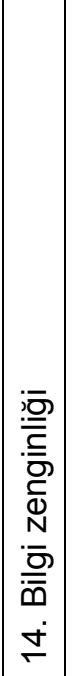 & 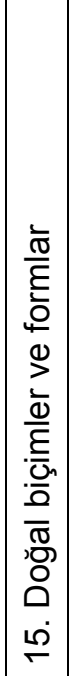 & 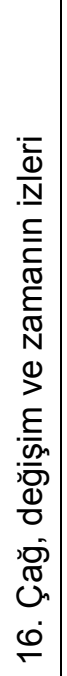 & 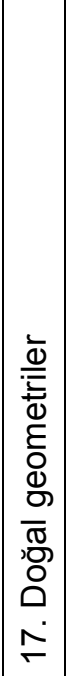 & 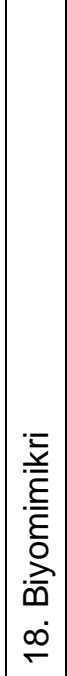 & 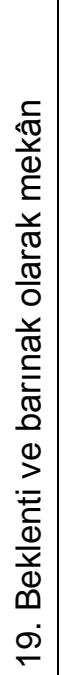 & 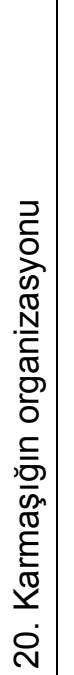 & 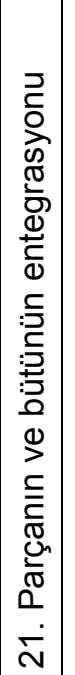 & 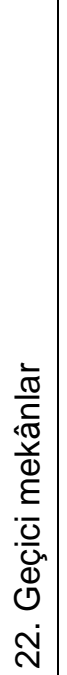 & 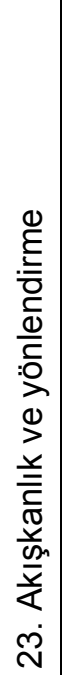 & 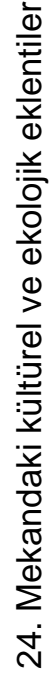 \\
\hline
\end{tabular}

Şekil 1. Kellert ve Calabrese'nin belirlediği biyofilik tasarım deneyimleri

Bu sınıflamaya çok benzer özellikler taşıyan, ancak doğanın doğrudan ve dolaylı deneyimlenmesini mekândaki doğa başlığı altında birleştiren Browning ve arkadaşları (2014, s.23), doğadan esinlenerek üretilen benzerlikleri ikinci başlıkta, deneyimlenen mekânı da üçüncü başlık altında, toplam 14 deneyimle açıklamıştır. (Şekil 2). "14 Patterns of Biophilic Design / Improving Health \& Well-Being in the Built Environment" kitabında açıklanan bu 14 deneyim, yapılı çevrede sağlığı ve esenliği iyileştirici bir güç olarak tanımlanmakta ve iç mimari tasarıma dair referansalar içermektedir. Bu nedenle bu çalışmada da bu sınıflama esas alınmıştır. Yine bu çalışma özelinde biyofilik tasarım deneyimleri iç mekân tasarımı açısından birer tasarım ilkesi olarak da kabul edilebilir. Ancak metin boyunca karmaşaya sebep olmamak adına deneyim tanımı kullanılmıştır. 


\begin{tabular}{|c|c|c|c|c|c|c|c|c|c|c|c|c|c|}
\hline \multicolumn{7}{|c|}{ Mekândaki Doğa } & \multicolumn{3}{|c|}{ Doğal Benzerlikler } & \multicolumn{4}{|c|}{ Mekânın Doğası } \\
\hline 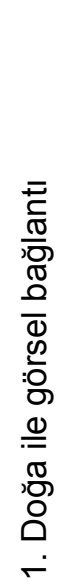 & 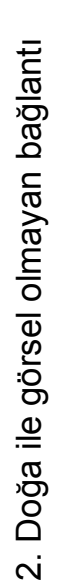 & 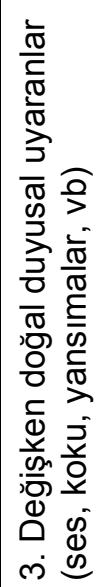 & 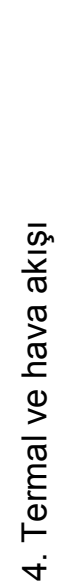 & 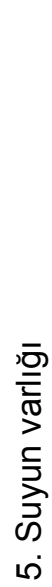 & 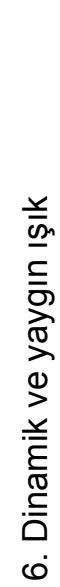 & 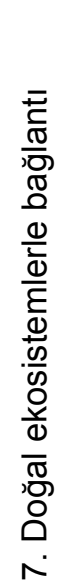 & 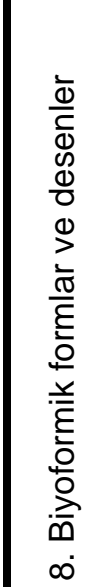 & 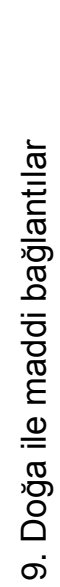 & 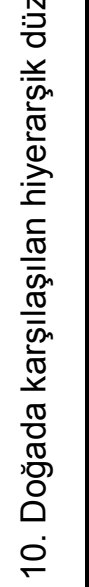 & 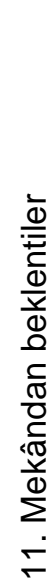 & 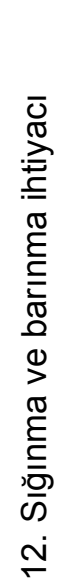 & 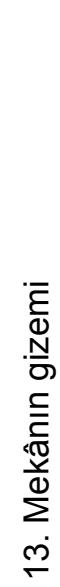 & 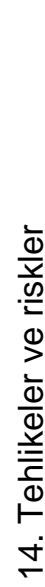 \\
\hline
\end{tabular}

Şekil 2. Browning ve diğ.'nin belirlediği biyofilik tasarım deneyimleri/ilkeleri

Mimari yapılarda biyofilik tasarımı inceleyerek, ne tür deneyimlere imkân vermesi gerektiğini irdeleyen birçok çalışmada farklı sınıflandırmaların yapıldığı görülmektedir. $\mathrm{Bu}$ çalışmalarda yukarıda belirtilen sınıflamalar esas alınmıştır ancak eleştirilen, eklenen ya da yer değiştiren başlıklar bulunmaktadır (Ramzy, 2015; Messelmani, 2018).

Hangi sınıflama esas alınırsa alınsın biyofilik tasarımdan söz edebilmek için doğanın iyileştirici gücü esas alınarak yapının doğa ile dolaylı ya da dolaysız bütünleşmesinin yanı sıra, kullanıcı tarafından da bunun deneyimlenmesi gerekmektedir. Yapının doğa ile kurduğu bu güçlü bağlantı kısa vadede yapıyı ve yapı çevresini değiştirebilir ancak ekolojik etkileri uzun vadede ve kentsel düzeyde ele alınması ile başarıya ulaşabilir. Bu anlamda biyofilik tasarımın mimaride bina ölçeği dışına taşarak kentsel düzeyde ele alınmasına vurgu yapan birçok çalışma bulunmaktadır. Sadece binaların bu anlayışla tasarlanmasının yeterli olmayacağını belirten Beatley (2011) biyofilik şehirciliğin desteklenmesi gerektiğini, kentlerin tasarımında, planlanmasında ve yönetilmesinde doğanın ve doğal sistemlerin ön plana alınmasının önemini savunmaktadır. Bu görüşü destekleyen Russo ve Cirella'da (2017) biyofilik anlayışla tasarlanan kentlerin uzun vadede su ve hava kalitesinin artması, karbondioksit tüketiminin azalması, su taşkınlarının kontrolü, ekosistemin düzelmesi, gıda üretiminin kalitesi ve ekonomik faydalar gibi yararları olacağını öngörmektedir. Bu konu üzerinde yapılan bir çok çalışma üçüncü nesil kentlerin inşa sürecinde bu tasarım yaklaşımının kullanılabileceğini, ancak bunun uygulama süreçlerindeki zorlukların da farkında olunması gerektiğini ortaya koymaktadır (Derr ve Lance, 2012; Scharoun ve Montana, 2013; Ojamaa, 2015; Onuk ve diğ., 2015; Düzenli ve diğ., 2017; Downton ve diğ.; 2017; Al-Rhodesly ve diğ, 2018; Zari, 2019). Yapılan deneysel çalışmalar da biyofilik tasarımın kentler için bir fırsat olduğuna, mimari dokuya küçük müdahalelerle uygulanabilirliğine işaret etmektedir (Fischl, 2016).

Görüldüğü gibi biyofilik tasarım hakkında belirtilen görüşler iç mekândan bina ölçeğine, bina çevresinden kente yayılan bir anlayışı öngörmektedir. Çünkü yapılan bilimsel çalışmalar, yapıların ve kentlerin doğa ile ilişkisinin güçlendirilmesiyle insanların ruhsal ve bedensel sağlığının da güçlendiğini göstermektedir. 


\section{Sağlık Yapıları ve Biyofilik Tasarım}

Yapılı çevrede insan memnuniyetinin en üst düzeyde olması gereken mekânlardan birisi sağlık yapılarıdır. Sağlık Bakanlığı'nın yayınladığı Sağlıkta Kalite Standartları'nda yeşil renk kullanımı ve hastane bahçelerinde yeşil alan kullanımı önerilmektedir (Anonim, 2020, s. 408). Biyofilik tasarımın sadece bir bölümünü oluşturan bu uygulamalar yeterli görülmemektedir. Bu nedenle bu çalışma biyofilik tasarımın sağlık yapılarındaki uygulama alanı üzerine yoğunlaşmaktadır. Çünkü biyofilik tasarımın özellikle iç mekânda insanı iyi hissettirme gücünün en fazla önem kazandığı alanlardan birisi sağlık sektörüdür.

Zumthor (1998, s.13) mimarlığın kendi alanı olduğunu ve yaşamla özel bir fiziksel ilişki kurduğunu söyler. Gerçekten de modern yaşamda günlük hayatının önemli bir bölümünü yapılı çevre içinde geçiren insan için mekânla kurulan temas, sağlık yapıları söz konusu olduğunda daha da önem kazanmaktadır.

21. yüzyılın küresel sağlık sorunları, insan intiyaçlarını bir bütün olarak dikkate alan yaklaşımlarla aşılabilir. Bu da ancak sağlık hizmetlerinin yeni bir tasarım anlayışının iyileştirici çevre vizyonuyla ele alınması ile mümkün olabilir (Totaforti, 2018). Sağlık yapılarında, yerine getirdiği işlevden dolayı stresin azaltılması, daha iyi bir ruh hali ile tedaviye başlanması için yeşilin mekân içindeki kullanımına sıkça rastlanmaktadır. Gullikson (2011) yapıların sürdürülebilir yeşil sertifika için biyofilik tasarımın bir fırsat olduğunu, ancak doğanın yapının içine serpiştirilmesinden ziyade insan tarafından deneyimlenebilir olmasının öneminden bahsetmektedir.

Connellan ve arkadaşları (2013) yapmış oldukları çalışmada 2000-2010 arası yayınlanan araştırmalar üzerinden sağlık yapılarında ruhsal sağlık ile mimarlık arasındaki ilişkiyi 13 madde üzerinden incelemiştir. Bu çalışmada biyofilik tasarıma vurgu yapılmasa da çalışmanın çıktıları arasında yer alan doğal ışık, yeşil bahçe, iç mekân tasarımı, sanat gibi birçok madde biyofilik tasarımı desteklemektedir. Sağlık yapılarında doğanın kullanımı üzerine birçok çalışması olan Ulrich (2008) hastanelerde stresin büyük bir problem olduğunu ve bunu biyofilik tasarım anlayışı ile azaltmanın mümkün olabileceğini araştırmalarıyla göstermektedir. Bu görüşü desteleyen sağlık yapıları özelinde birçok çalışma da (Gullone, 2000; Ulrich ve diğ., 2008; Hudson, 2013; Hidalgo, 2014; Gillis ve Gatersleben, 2015; Akrami, 2017; Habibi ve Akrami, 2018) biyofilik tasarım anlayışı ile düzenlenen yapılı çevrenin insan psikolojisi üzerinde olumlu etkisi olduğunu, stresi azalttığını, zihinsel yorgunluğun iyileşmesine yardım ettiğini güçlü kanıtlar ile ortaya koymaktadır.

\section{3. Çalışma Alanı ve Yöntem}

Biyofilik tasarımın iç mimaride uygulanabilirliğini bir sağlık yapısı üzerinden incelemeyi temel alan bu çalışmanın alanı olarak İstanbul Memorial Bahçelievler Hastanesi seçilmiştir. Hastanenin seçilme nedeni; USGBC (United States Green Building Council/Amerikan Yeşil Binalar Konseyi) tarafından yürütülen sertifikasyon programları arasında en yüksek derecelendirme anlamına gelen, enerji ve çevre dostu tasarımda lider konumdaki kurumlara verilen ve en prestijli yüksek yeşil bina sertifikası olan "LEED Platinum" belgesini dünyada ve Türkiye'de tam donanımlı hastaneler arasında ilk kez kazanmış olmasıdır. Ayrıca JCl (Joint Comission International) Akreditasyon Kalite Belgesi'ni alan Türkiye'de ilk, dünyada 21. hastanedir. JCl Akreditasyon Kalite Belgesi, hasta ve yönetim merkezli olmak üzere iki ana başlık altında ifade edilebilecek birçok alt başlığı bulunan sağlık hizmetlerinin kalitesini ve güvenliğini artırmaya yönelik hizmet vermekte olan ve kâr amacı gütmeyen JCAHO (Joint Commission on 
Accreditation of Healthcare Organizations)'ya ait $\mathrm{JCl}$ birimi tarafından gerekli standartlara sahip sağlık kuruluşlarına verilen bir belgedir (Anonim, 2014).

Bunun yanı sıra hastanenin tasarım ekibi olarak belirttiği "yeşil hastane konsepti" ve "sanatın iyileştirici gücü" gibi mottolar da bu seçimde etkili olmuştur. Memorial Proje Grup Müdürü Mimar Fulden Baran Toz, binalarla doğa ile insanın bağının koptuğunu ancak bu hastane tasarımında buna dikkat ettiklerini, bol yeşil alana yer verdiklerini ve bol gün ışığı almaya çalıştıklarını, hasta odalarında doğal havalandırma olmasına önem verdiklerini ve açılabilir camlar yerleştirdiklerini, doğadan gelen dingin, toprak tonları renkleri kullandıklarını, hastaların kendini evde hissedeceği, endişe ve kaygı duymayacağı ortamlar yaratmaya çalıştıklarını, bina içinde yer alan görsellerde doğa unsuruna ve yeşile yer verdiklerini belirtmektedir (URL-1, 2021).

Hastanenin iç mekân tasarımını üstlenen ZOOM/TPU da hasta odaklı bir tasarımı temel aldıklarını, iyileştirici çevre yaklaşımı çerçevesinde hastalar üzerinden edinilen deneyimlerle, hastanenin tüm noktalarında iyileşme hissiyatı gözetilerek doğanın yapı içerisine malzeme, renk, doku, ışık gibi özellikleri ile entegre olmasını sağlayan bir tasarım yaklaşımını benimsediklerini söylemektedirler (Yüksel, 2018; URL-2, 2021; URL-3, 2021).

Hastanenin kendi internet sayfasında da şu açıklama yer almaktadır (URL-4, 2021) :

"Çevreye duyarlı bir anlayışla inşa edilen Memorial Bahçelievler Hastanesi'nin iç ve dış mekânları, yeşil alanların insan sağlığına ve psikolojisine olumlu etkileri göz önünde bulundurularak tasarlandı. Tüm mevsimleri yaşatacak, yaşam döngüsü ve biyoritmi hastaneye taşıyacak canlı bitkiler; hasta ve hasta yakınları ile çalışanları doğanın içinde hissettiriyor. Alerjik olmayan doğal bitkilerin tercih edildiği peyzaj düzenlemesi, şehrin mimarisine de estetik bir görünüm katıyor. Memorial Bahçelievler Hastanesi çevreye duyarlıığını, enerji veriminden atık yönetimine, sürdürülebilir alan planlamasından iç ortam kalitesi gibi kriterlere göre inşa edildi. Memorial Bahçelievler Hastanesi, yeşilin ve sanatın iyileştirici gücünün mimariye yansıtıldığı, hasta ve yakınlarının psikolojisi üzerindeki pozitif etkileri nedeniyle, gün ışığının maksimum düzeyde kullanıldığı "zamansız tasarımlarıla" da dikkat çekiyor. Memorial'in deneyimli proje ekibinin liderliğinde; akustik, peyzaj, aydınlatma ve tasarım konusunda ünlü danışmanlar tarafından oluşturulan Memorial Bahçelievler'in ana temalarından birini "sanat" oluşturuyor."

Bütün bu söylemler ve tasarım yaklaşımları ile Memorial Bahçelievler Hastanesi biyofilik tasarımın bir uygulama alanı olarak değerlendirilmiştir. Çalışmada yöntem olarak biyofilik tasarımı14 madde altında toplayan Browning ve diğerlerinin (2014) sınıflandırıması esas alınmıştır. Çünkü bu çalışmada biyofilik tasarımın insan üzerindeki bilişsel, psikolojik ve fizyolojik etkilerini araştıran çalışmalara odaklanmaktadır. Yapılı çevre memnuniyetinin stresi azaltabileceği, yaratıcılığı ve düşünme kapasitesini artırabileceği, sağlığı iyileştirebileceğini ya da iyileşmeyi hızlandırabileceğinden hareketle insanın doğa ile bağlantısının kurulabilmesi için mimaride biyofilik tasarımın bir araç olabileceğini savunmaktadır. Bu amaçla Browning ve diğerlerinin (2014) mimari uygulamalar için 3 başlık altında sundukları 14 deneyim bu hastane özelinde incelenmiştir. Öncelikle her bir deneyim Browning ve diğerlerinin (2014) tanımladığı şekilde açıklanmış, daha sonra da incelen hastane tasarımında bu deneyimlerin nasıl yansıtıldığı görsellerle desteklenerek yorumlanmıştır. Sonuçlar bölümünde ise mekânı deneyimlerken algılanan duyular üzerinden bir tablo oluşturularak bu ilişki tartışılmıştır. 


\section{Memorial Bahçelievler Hastanesi ve Biyofilik Tasarım İlişkisi}

Bahçelievler, kilometrekare başına yaklaşık 35 bin kişi ile İstanbul'un en yoğun ilçelerinden bir tanesidir (URL-5, 2021). Bu nedenle yapı yoğunluğu oldukça fazladır. Memorial Bahçelievler Hastanesi de etrafında yoğun yapılanma ve karayolu trafiği ile çevrilmiş bir ada parsel üzerinde merkezden dağılan 4 kol şeklinde tasarlanmıştır (Şekil 3). Arsa bedeli yüksek, yapı yoğunluğu fazla olan bu arazide toplamda $72.000 \mathrm{~m}^{2}$ alanının $8.000 \mathrm{~m}^{2}$ 'lik bölümü yeşil alana ayrılmıştır. Yapı cephesi kademeli olarak içeri çekilerek kat bahçeleri oluşturulmuş, bu sayede çevrenin yapı ve trafik yoğunluğundan izole edilmeye çalışılmıştır (Yüksel, 2018). Yeşil hastane konseptiyle tasarlanan yapının tasarımcıları "zamansız tasarım" ilkesiyle sanatın ve yeşilin iyileştirici gücünü kullanmaktadır. Sadece hastaların değil, hasta yakınlarının da hastane içinde geçirdikleri zaman kalitesini artırmaya yönelik tasarımlar geliştirmişlerdir (Ulusoy, 2021, S. 129)

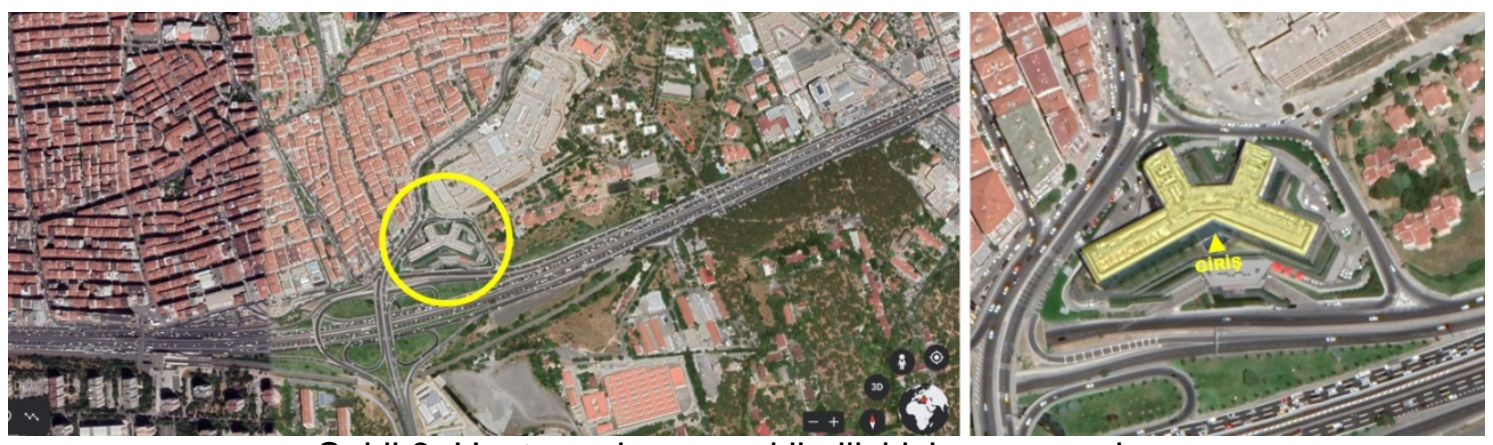

Şekil 3. Hastanenin çevresi ile ilişkisi ve yapı adası

Biyofilik tasarımın yapılı çevrede sağlığı ve iyileştirici gücü için tanımlanan 14 deneyim, doğanın mekan içinde doğrudan deneyimlenmesi, doğadan esinlenilen formların yapı içerisinde tasarıma dönüşmesi ve mekanın kendi yarattığı atmosferin insan üzerinde hissedilmesi şeklinde 3 ana başlık altında toplanmıştır (Browning ve diğ., 2014, s.23). Her deneyimin kendisine özel belirleyicileri bulunmakla beraber, diğer deneyimlerden de bağımsız değil, ilişkilidir. Örneğin doğal ekosistemlerle bağlantı deneyimi yapının güneş enerjisi, atık suyun dönüştürülmesi ya da yağmur suyunun toplanarak değerlendirilmesi gibi özelliklerinin yanı sıra doğal ışık, doğal havalandırma gibi deneyimleri de içerir. Ancak doğal ışık ve doğal havalandırma ayrı başlıklar altında da biyofilik tasarım deneyimleri olarak verilmektedir. Bu nedenle her deneyimin diğer deneyimlerle bağlantısı kurulabilir. Belirtilen 3 ana başlık mekândaki doğa, doğal benzerlikler ve mekânın doğasıdır. Mekândaki doğa; doğa ile görsel bağlantılar, doğa ile görsel olmayan bağlantılar, değişken doğal duyusal uyaranlar, termal ve hava akışı, suyun varlığı, dinamik ve yaygın ışık, doğal ekosistemlerle bağlantı deneyimlerini içermektedir. Doğal benzerlikler; biyoformik formalar ve desenler, doğa ile maddi bağlantılar, doğada karşılaşılan hiyerarşik düzen deneyimlerini içermektedir. Mekânın doğası ise; mekândan beklentiler, sığınma ve barınma ihtiyacı, mekânın gizemi, tehlike ve riskler deneyimlerini içermektedir. Biyofilik tasarım için deneyim olarak belirlenen bu ana başlıkların her biri tek tek ele alınmış ve açıklanmıştır. Daha sonra alt başlıklar da tanımlanarak, uygulama alanı ile bu deneyimin nasıl sağlandığı görsellerle desteklenmiş ve yorumlanmıştır. 


\subsection{Mekândaki Doğa}

Mekândaki doğa, mekânın içinde doğrudan fiziksel olarak deneyimlenmesi ya da varlığı ile tanımlanabilir. Doğa direkt olarak yapı içinde yer alabileceği gibi (saksı bitkileri, yeşil duvarlar, avlu bahçeleri, bitki örtülü çatılar, kafes hayvanları, akvaryum, su öğeleri, şömine vb.), doğal ışık, hava, ses, koku gibi duyusal olarak da var olabilir. Bu anlamda mekânda doğayı doğrudan deneyimlemek mümkündür. Ayrıca doğayı hatırlatan görsel unsurlar da bu madde içinde yer alabilirler. Mekândaki doğa 7 alt başlıkta verilmiştir (Browning ve diğ., 2014, s.9).

\subsubsection{Doğa ile Görsel Bağlantı}

Doğanın mekân içindeki fiziksel varlığı ve kullanımıdır (Browning ve diğ., 2014, s.24). Yapının kademeli yerleşiminden yararlanılarak peyzaj mimarları ile beraber $8000 \mathrm{~m}^{2}$ alanı yeşil alan olarak tasarlanmıştır. Kat bahçelerine imkân veren bu tasarım anlayışı ile özellikle bekleme ve dinleme alanları ile ilişkili olan bu mekânlara çıkabilmektedir. Ayrıca çocuk polikliniğinde bir iç avlu düzenlenerek çocuk parkı yapılmıştır (Şekil 4). Kara trafiğinin yoğun kullanımı arasında sınırlı bir parselde tasarlanan yapı için bu yeşil alanlar çok önemli bir nefes alma noktalarıdır.
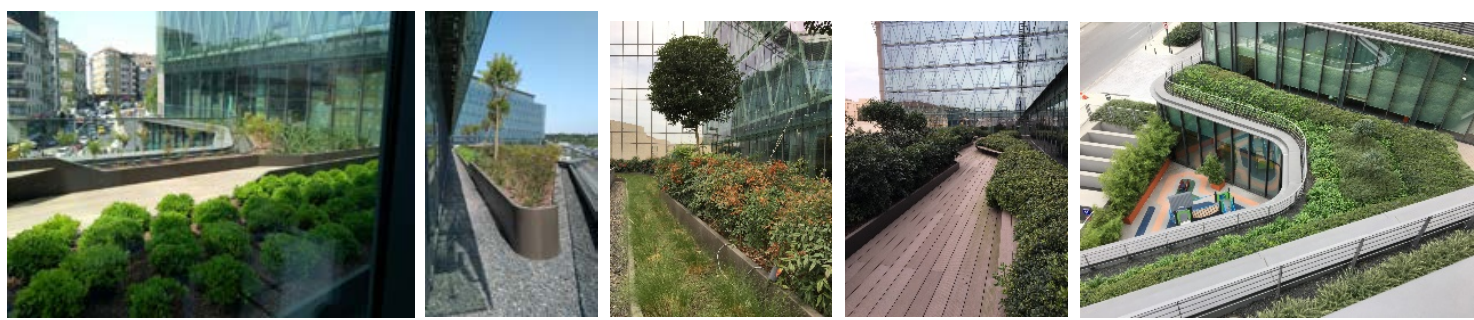

Şekil 4. Yapıdaki doğa ile görsel bağlantı görselleri (Erbay, 2019; Baran Toz, 2021)

\subsubsection{Doğa ile Görsel Olmayan Bağlantı}

Doğanın mekân içindeki yapay/fiziksel görüntüleridir (Browning ve diğ., 2014, s.26). Yapı içerisinde bekleme alanlarında cam katmanlar arasında kademeli bir görüntü elde ederek yerleştirilen yapay bitki ve resimlerle doğa etkileşimi sağlanmaktadır. Aynı anlayışla yapılan toplantı salonunda da çalışanlar için doğa düşünülmüştür. Hastalar için ruhsal açıdan kendini kötü hissettirebilecek mekânlardan birisi olan radyolojik görüntüleme alanlarında da gergi tavan/duvar uygulamaları üzerine doğadan figürler yerleştirilmiştir (Şekil 5).
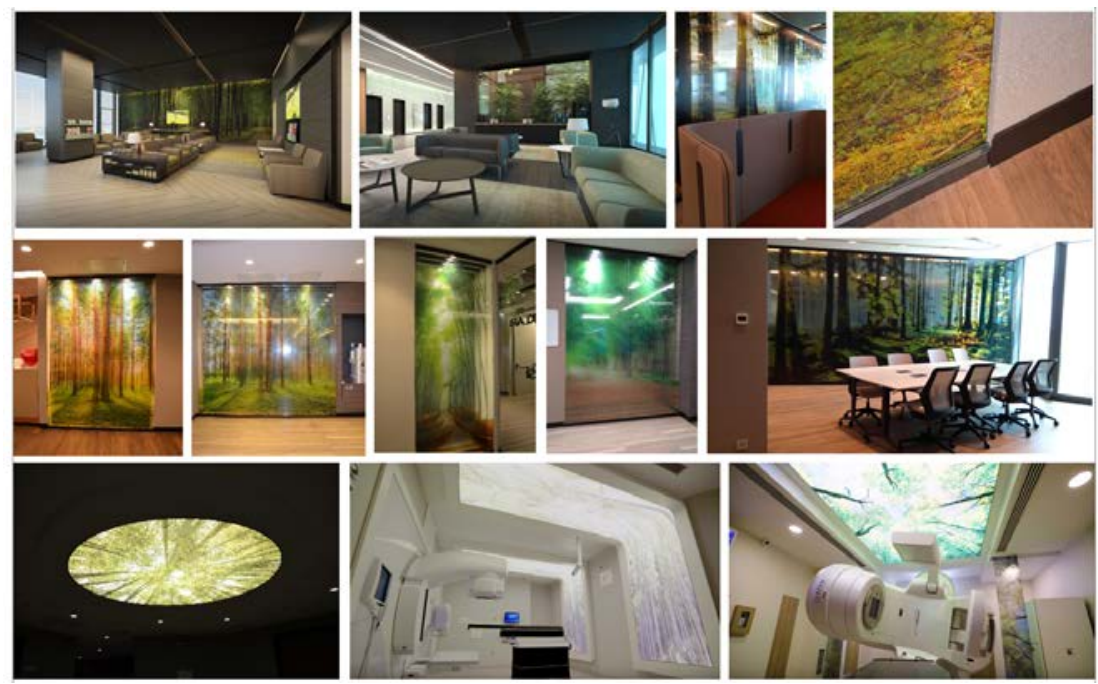

Şekil 5. Doğa ile görsel olmayan bağlantı görselleri-1 (Erbay, 2019) 
Bir başka doğa ile bağlantı, resim galerilerinden alınmış doğa resimleridir. Hastanenin bekleme alanı ve koridorlarında rastlanabilen tekil doğa resimlerinin yanında sanat galerisi adı altında toplanan toplu resimler de sergilenmektedir. Bazı koridorlarda da dijital ekranlarda değişen doğa görüntüleri bulunmaktadır (Şekil 6).
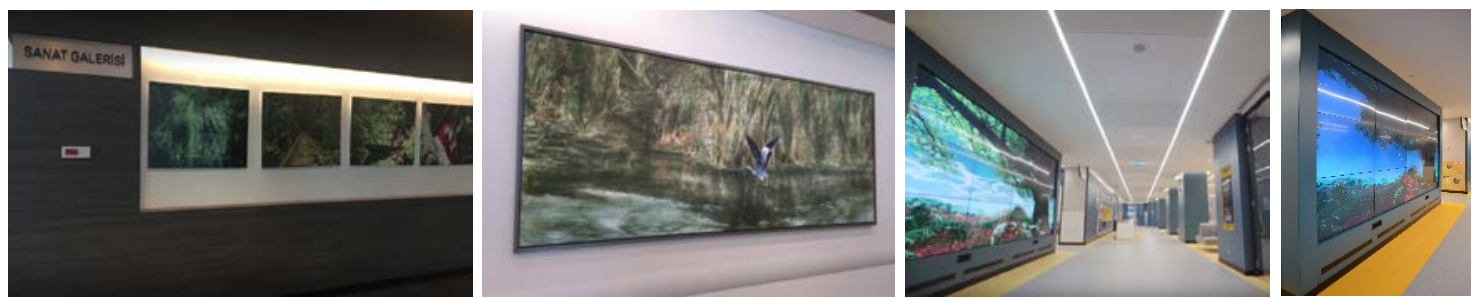

Şekil 6. Doğa ile görsel olmayan bağlantı görselleri-2 (Erbay, 2019)

Ayrıca poliklinikler doktor odaları için seçilen tablolar bilinçli olarak doğa temalı seçilmiştir. 1800'lü yıllarda yaşamış olan kuş gözlemcisi ve ressam John James Audubon tarafından resmedilmiş Kuzey Amerika kuşlarının 435 gerçek boyutlu suluboyasını içeren "Birds of America" kitabından (URL-6, 2021) Mimar Gökhan Karakuş'un danışmanlığında seçilen eserler doğa ile insanı yakınlaştırmaktadır.

Yapının giriş holünde yürüyen merdiven aksında PIN Architects imzalı "Notch (Inselberg)" isimli bir enstalasyon sanat eseri bulunmaktadır. Mermeri mimari ve tasarım projelerine dâhil ederek bütünleştirmeyi amaçlayan Silkar Madencilik'in inovatif mermer ürünü akdolam kullanılarak geliştirilen biyofilik tasarım odaklı enstalasyon çalışması (URL-7, 2021) AKDO'nun “Mermer Bahçe: Biyofilik Tasarım” yarışmasını da kazanmıştır (Şekil 7).
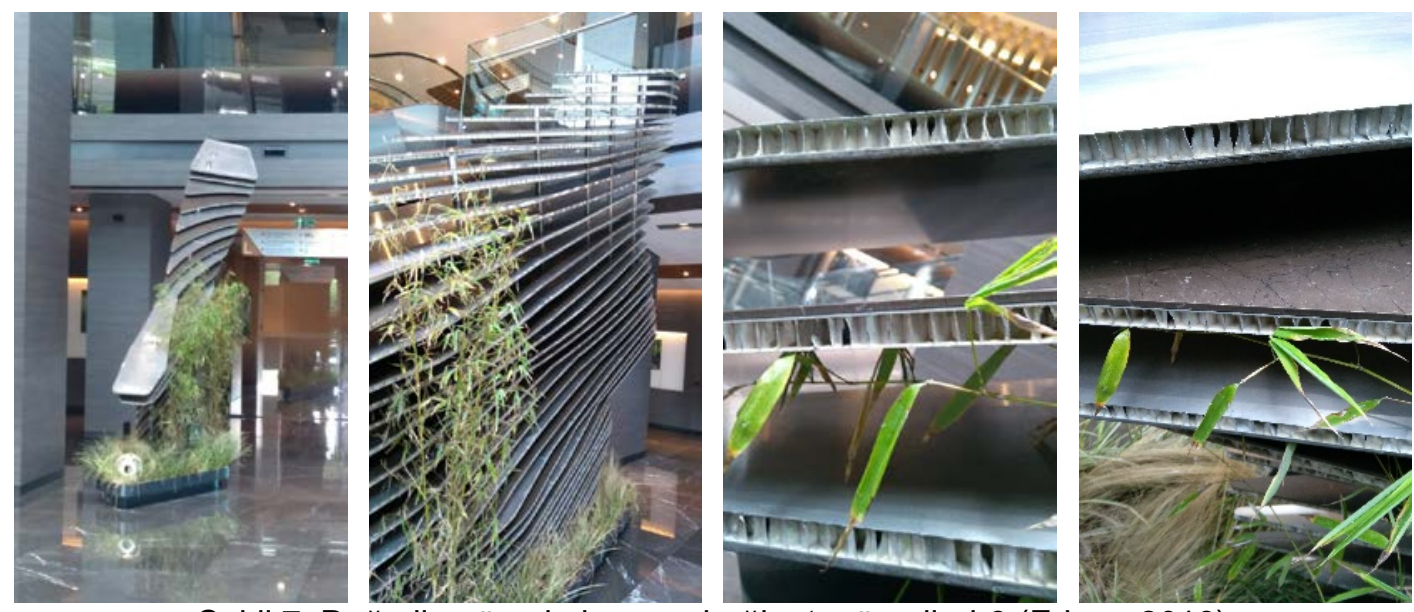

Şekil 7. Doğa ile görsel olmayan bağlantı görselleri-3 (Erbay, 2019)

\subsubsection{Değişken Doğal Duyusal Uyaranlar}

Doğanın asla durağan olmadığı, her zaman hareket ediyor, büyüyor ve uyum sağlıyor olmasından hareketle doğal seslere ve kokuların anlık duyusal olarak algılanması insan fizyolojisi üzerinde olumlu etkiler vermektedir (Browning ve diğ., 2014, s.28). Yapının duyusal açıdan algılanmasına hizmet eden üç öge sayılabilir. Bunlardan ilki yapının girişinde deneyimlenen özel koku tasarımıdır. Hastaneye özel olarak tasarlanan bir kokunun havaya salınması, ilk girişte hastane algısını tersine çevirmektedir. Bir başka duyusal algı aracı ise müziktir. Yine yapının girişinde yer alan piyano otomatik olarak klasik müzik eserlerini çalmaktadır. Giriş salonunda yer alan bir başka eser de Prix ve Nohlab işbirliği ile oluşturulan üç kat yüksekliğinde devam eden dijital sanatın ilgi çekici örneklerinden birisi olan Ab-ı Hayat'tır. "Hayat veren su" anlamına gelen eser, müziğin 
ve renklerin insanlar üzerindeki olumlu etkilerinden yola çıkılarak oluşturulmuş, her biri kendi içinde farklı hikâyeler anlatan, ancak bütün olarak bakıldığında tek bir eser halini alan 48 dijital ekrandan oluşmaktadır. Sanatın iyileştirici gücü, güven odaklı hastane deneyimi teması ile ArtBizTech'in tasarım odaklı düşünme metodolojisinin kullanıldığı dijital eser döngüsünü 3 dakikada tamamlamaktadır (URL-8, 2021) (Şekil 8).
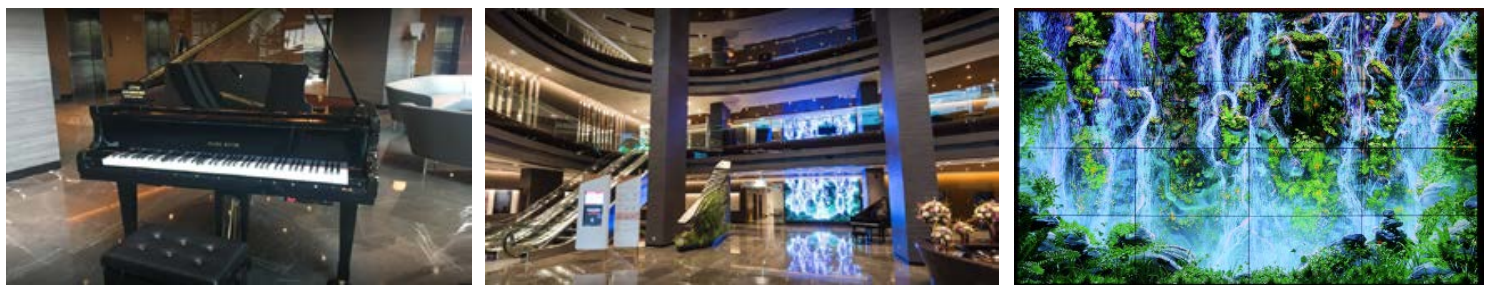

Şekil 8. Yapıdaki müzik ve dijital sanat, (Erbay, 2019)

\subsubsection{Termal ve Hava Akışı}

Doğal hava akımının mekânda hissedilmesidir (Browning ve diğ., 2014, s.30). Yapıda mümkün olan her alanda doğal havalandırma kullanılmıştır. Hasta odaları ve polikliniklerde doktor odaları camları açılabilir tasarlanmıştır. Bekleme alanlarından teraslara çıkışlar, çocuk polikliniğinde avluya çıkış, toplantı salonlarından balkon çıkışları ile doğal hava akımı sağlanmaktadır.

\subsubsection{Suyun varlığı}

Suyun sakinleştirici ve iyileştirici gücünden yararlanmak için görerek, sesini duyarak ya da dokunarak deneyimlemektir (Browning ve diğ., 2014, s.32). Yapıda hijyen ön planda olduğu için su ögesi az ama etkili bir şekilde kullanılmıştır. Ana girişin hemen dışında yer alan yapay su havuzunun giriş saçağında ve bekleme salonundaki yansıma etkisi, giriş salonunda bekleyenler üzerinde rahatlatıcı bir etki yaratmaktadır Ayrıca üst kattan yapay su havuzu ile kurulan görsel temas da bu etkiyi güçlendirmektedir. Giriş salonunda yer alan duyusal algı maddesinde belirtilen Ab-ı Hayat eseri bir yandan da görsel olarak suyun akışkanlığını sergilemektedir. Aynı zamanda müziğin içinde yer alan su sesleri de su varlığı deneyimini yaşatmaktadır (Şekil 9). Bodrum katta bulunan ibadethanelerin giriş holünde de su ögesi kullanılarak mistik bir ortam sağlanmıştır (Şekil 10).

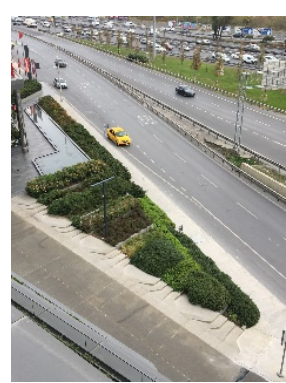

Şekil 9. Girişteki yansıma havuzu ve gi

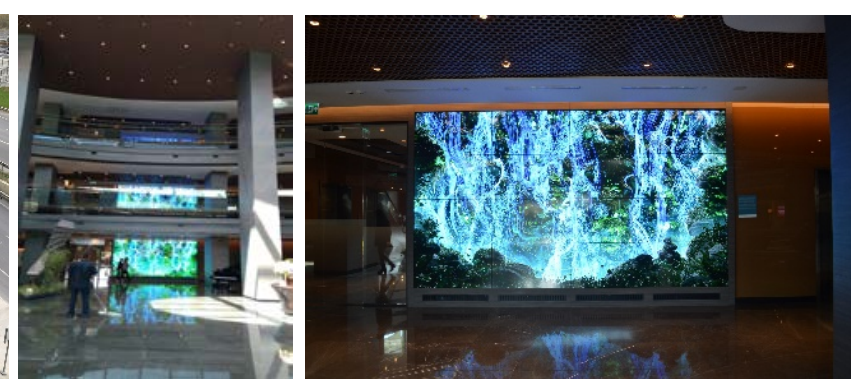

2019; Baran Toz, 2021)

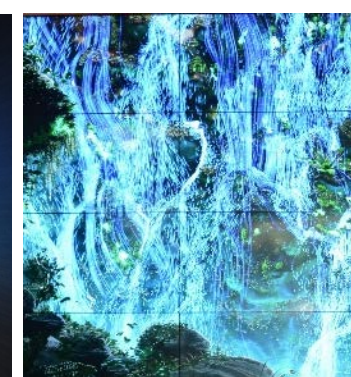

edya mimarisi (Erbay, 

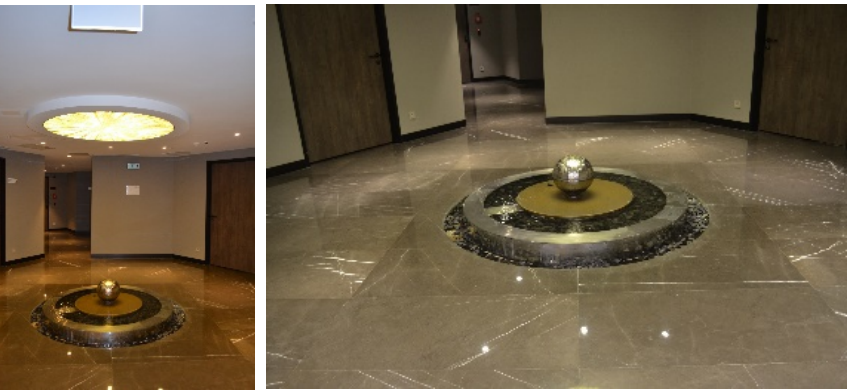

Şekil 10. İbadethane holü ve su ögesi (Ulusoy, 2019)

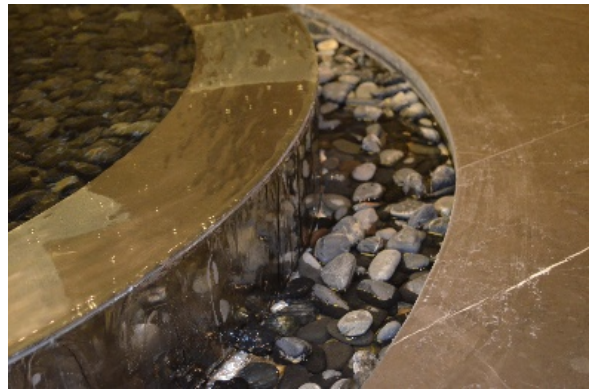

\subsubsection{Dinamik ve Yaygın Işık}

Mekânda gün ışığının maksimum düzeyde kullanımıdır (Browning ve diğ., 2014, s.34). Yapıda gün ışığı girişte üç kat boyunca devam eden galeri boşluğunun üzerini kaplayan cam tavan sayesinde güçlü bir şekilde hissedilmektedir. Ayrıca lineer planlamadan dolayı tüm hasta odaları, doktor odaları doğal ışık almaktadır. Bunun yanı sıra bekleme ve toplantı salonlarında da gün ışığı en üst düzeyde kullanılmıştır (Şekil 11).
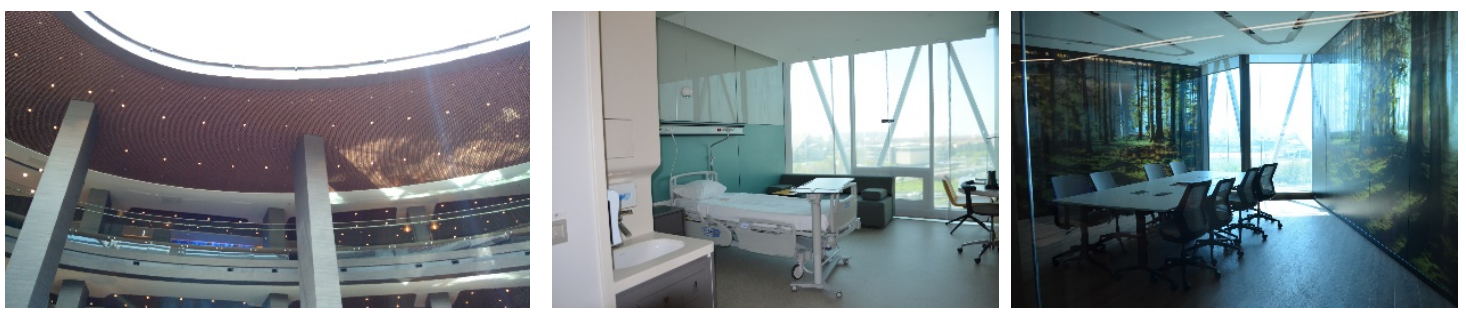

Şekil 11. Gün ışığı alan mekânlardan örnekler (Erbay, 2019)

\subsubsection{Doğal Ekosistemlerle Bağlantı}

Güneş enerjisi, rüzgâr enerjisi, yağmur suyunun/atık suların toplanması, arıtılması ya da değerlendirilmesi, sürdürülebilir malzemelerin kullanımı ile doğal havalandırma, doğal ışık gibi ayrı başlıklarda değerlendirilen deneyimler ekosistemlerle bağlantıyı oluşturmaktadır (Browning ve diğ., 2014, s.36). Yapıda ekosistemlerle doğal bağlantı noktaları doğal havalandırma, doğal aydınlatma ve doğal malzemelerdir. Tasarım ekibi yerli üreticilerin çevre dostu malzemelerin sertifikasyon süreçlerini henüz tamamlamadıkları için özellikle sürdürülebilir malzeme konusunda mümkün olduğunca doğal malzemeleri tercih ettiklerini belirtmektedirler. Yapıda kojenerasyon sistemi ile elektrik üretimi yapılmakta ve ısıtma sağlanmaktadır. Ancak bu sistemde yakıt olarak doğal gaz kullanılmaktadır.

\subsection{Doğal Benzerlikler}

Doğal benzerlikler doğada bulunan formların kumaş, halı, duvar kâğıdı, yüzey, tasarım ve mobilya detaylarında kullanılmasıdır. Doğanın organik, cansız ve dolaylı çağrışımları ile anılabilir. Bu çağrışım nesne, malzeme, renk, şekil, dizi ve desenler, doğa, sanat eseri, süsleme, mobilya, dekor, tekstil yolu ile olabilir. Özellikle organik şekilli kabuklar, mobilyalar, işlenmiş doğal malzemeler bu bağlantıyı güçlendiren unsurlardır. Bu anlamda biyofilik formlar ve desenler, doğal malzeme kullanımı ve doğadaki hiyerarşik düzenin kullanılması gibi 3 alt başlıkta deneyimlenmesidir (Browning ve diğ., 2014, s.10).

\subsubsection{Biyomorfik Formlar ve Desenler}

Doğadaki biçimlerin oranlarının incelenmesi ile ortaya çıkan altın oran ve Fibonacci sayıları mimarlıkta da tasarım ilkelerinden ritim ve düzen başlığı altında sıklıkla 
kullanılmaktadır. Bunların kullanılmasının nedeni insanın doğada algıladığı o düzeni insan eli ile yapılmış bir nesnede ya da formda gördüğü zaman kendisini daha rahat hissetmesidir. Biyoformik formların ve desenlerin kullanılmasının amacı da bu temsiliyeti sağlamaktır (Browning ve diğ., 2014, s.38). Bu anlamda yapıda iki tür kullanımdan söz edilebilir. Birincisi biyoformik formlar, ikincisi ise doğadan esinlenilerek oluşturulmuş desenlerdir. Biyoformik formlar yapının iç mekânında oluşturulan strüktürlerde, döşeme ve tavan detaylarında, donatılarda yoğun olarak hissedilmektedir (Şekil 12). Doğadan esinlenilerek oluşturulan desenler de yüzey tasarımlarında göze çarpmaktadır (Şekil 13).
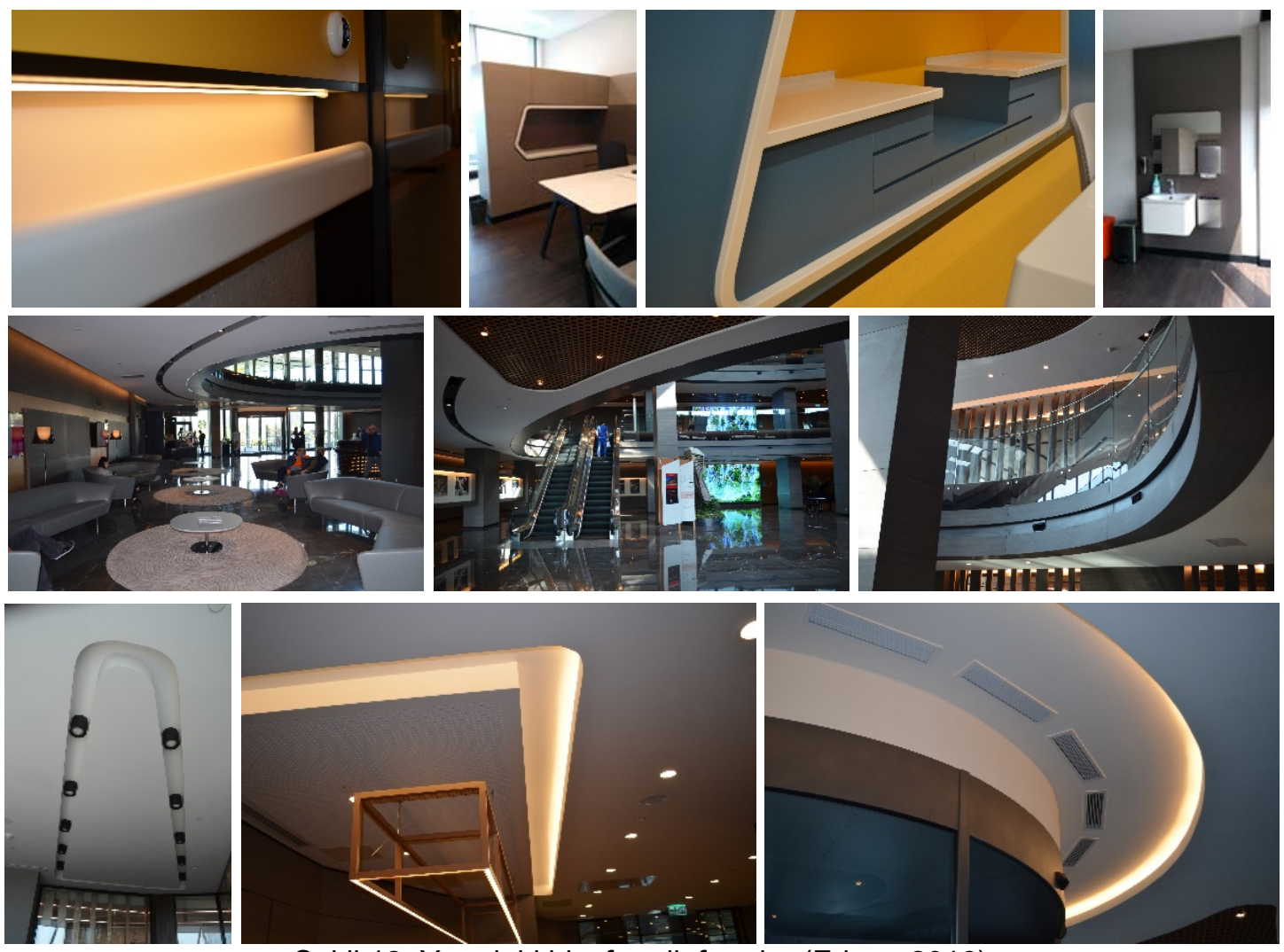

Şekil 12. Yapıdaki biyoformik formlar (Erbay, 2019)
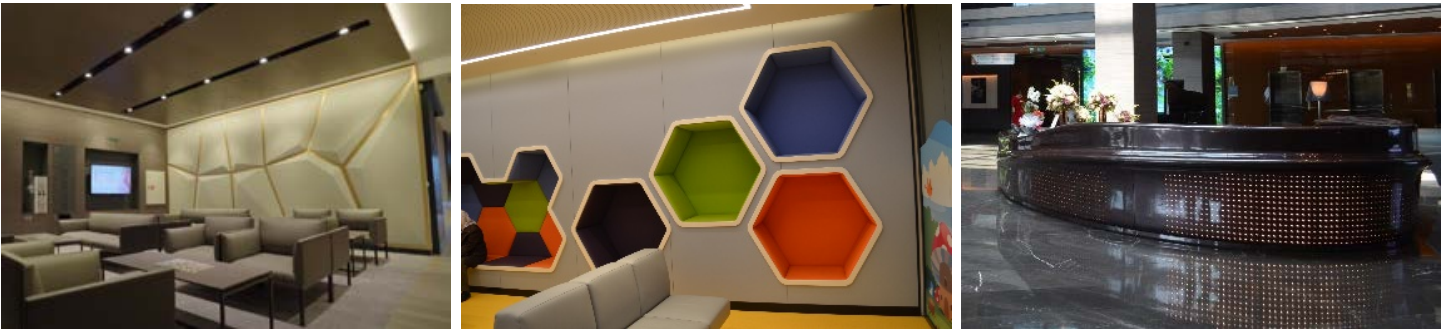

Şekil 13. Doğadan esinlenilerek oluşturulan desenler (Erbay, 2019)

\subsubsection{Doğa ile Maddi Bağlantılar}

Doğal malzemeler, doğal renk paletleri, doğal dokular doğa ile doğrudan ilişki kurmasa da doğayı çağrıştırırlar. Mekanda kullanılan deri, taş, ahşap dokusu, yeşil renk başta olmak üzere toprak renklerin ve taş, ahşap, mermer gibi doğal malzemelerin kullanımı ile bu bağlantı sağlanabilir (Browning ve diğ., 2014, s.40). Yapının iç mekânında ahşap, taş, mermer doğal renkleri ve dokuları ile kullanılmıştır. Buna uygun olarak döşeme kaplamaları, mobilyaların ve kaplamalarının renkleri de toprak tonlarındadır (Şekil 14). 

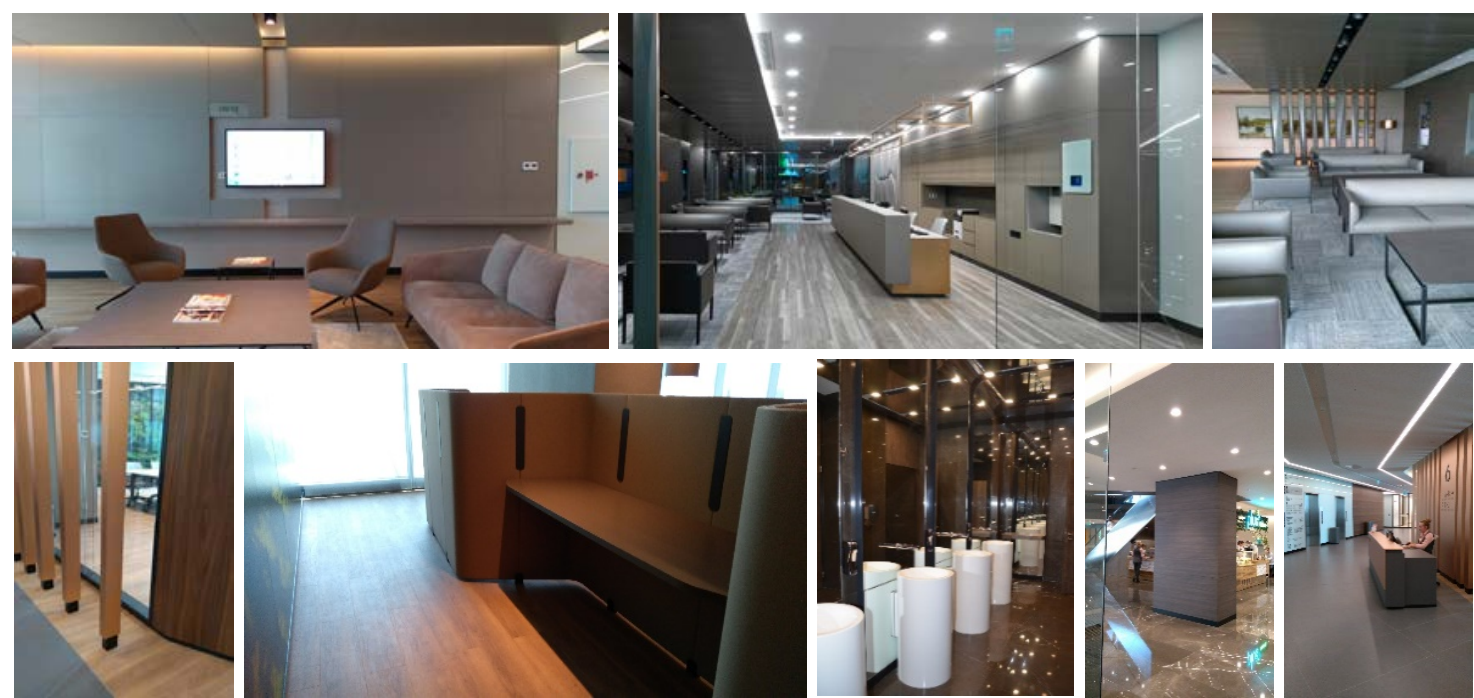

Şekil 14. İç mekândaki doğa ile maddi bağlantılar, malzeme, renkler ve dokular (Erbay, 2019)

\subsubsection{Doğada Karşılaşılan Hiyerarşik Düzen}

Mimarideki fraktal geometriler ve bunların sınırsız korelasyonu yapılı çevrede doğayı temsil ettiğinden doğa ile ilişki kurar. Uzaysal hiyerarşi ile üretilen bu geometriler insan psikolojisi üzerinde olumlu etkiler bırakabilmektedir. Ancak bu fraktallerin kullanım dozu artıkça rahatsızlık verebilir. $\mathrm{Bu}$ nedenle dozunda ve kararında kullanılmalıdır (Browning ve diğ., 2014, s.42). Yapının iç mekânında çeşitli yüzeylerde; tavan dokusunda, giriş bankosu üzerinde, toplantı salonu yüzeylerinde etkili bir şekilde kullanılmıştır (Şekil 15).

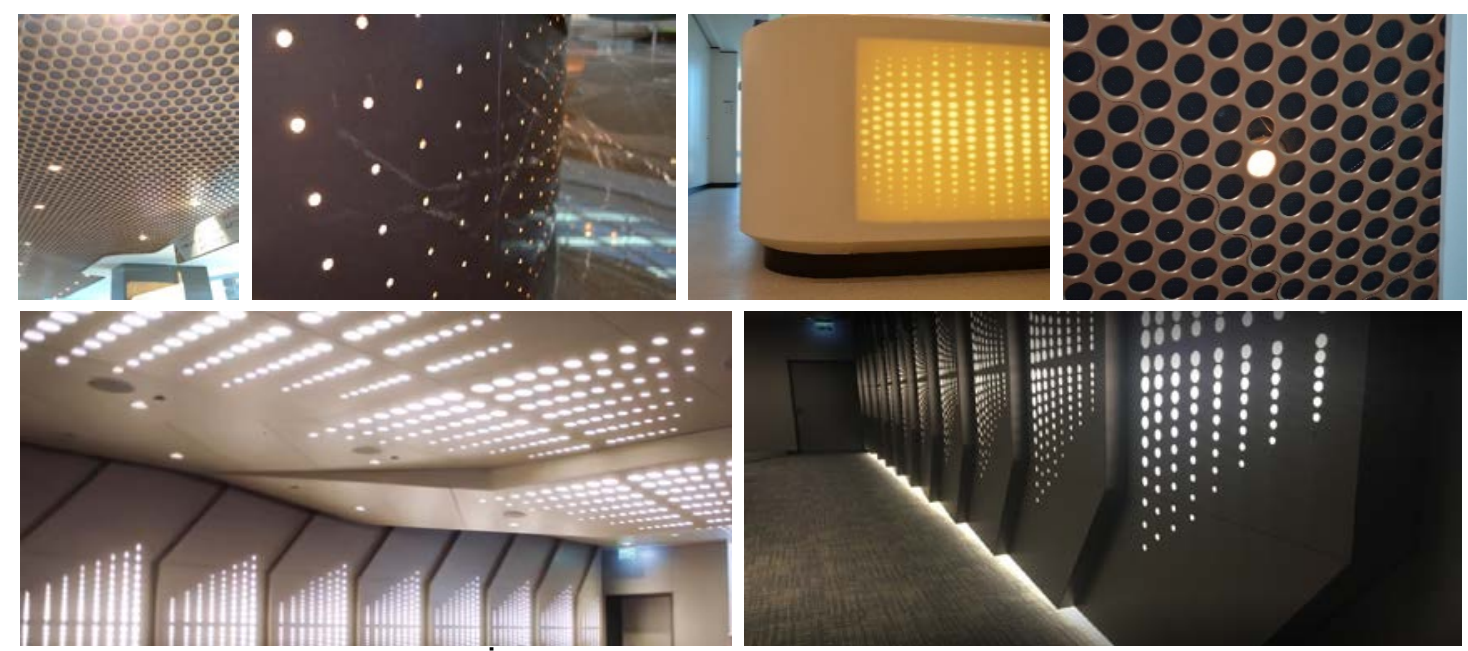

Şekil 15. İç mekândaki fraktal dokular (Erbay, 2019)

\subsection{Mekânın Doğası}

Mekânın doğası, doğadaki uzamsal yapılanmanın mekân içindeki yansımasıdır. Insanın bulunduğu mekânı bir doğal çevre gibi düşünerek keşfetme ve çevresinin bir adım ötesini öğrenme isteğidir. Bu nedenle insanın doğuştan gelen doğayı keşfetme arzusu, tehlikeli ve bilinmeze olan merakı, doğanın gizemi ve aynı zamanda da güvende olma hissi gibi unsurları içerir. (Browning ve diğ., 2014, s.10). Bu başlık altında mekândan beklentiler, sığınma ve barınma intiyacı, gizem, tehlike ve riskler altında 4 deneyim tanımlanmıştır. 


\subsubsection{Mekândan Beklentiler}

Doğada yaşamın devam etmesi için gereklilikler düşünüldüğünde bir mekânda da insan intiyaçlarını karşılaması için olması istenen unsurlardır. Temel mekânsal işleve bağlı intiyaçların yanı sıra kültürel antropoloji, evrimsel psikoloji ve mimari analiz ile doğa deneyimini yaşatmayı hedefler. Doğadaki açık ve özgür alanların hissedilebilmesinden hareketle iç mekânda da görsel sürekliliğin sağlanmasına yönelik düzenlemelerin yapılmasını önerir. Bunu sağlamak içinde açık geniş mekânlar, manzara açıklıkları, şeffaf, yarı şeffaf ya da alçaltılmış duvarlar, doğayı çağrıştıran manzaralar, sanat gibi ögeler kullanılabilir (Browning ve diğ., 2014, s.44). Yapı mekândan beklentileri işlevsel olarak karşıladığını zaten kanıtlamıştır. Bu anlamda mekândan beklentileri biyofilik tasarım deneyimi olarak nasıl karşıladığına bakılmıştır. Giriş salonundaki geniş, yüksek ve ferah alan, galerili atrium, cam tavan, koku, piyano, biyofilik sanat eseri, suyun ve yeşilin müzikle harmanlandığı dijital sanat ögesi bu deneyimi yaşatmaktadır. Ayrıca mekâna ilk girildiğinde yön bulma beklentisini güçlendiren tek kollu yürüyen merdiven, mekânın algılanması ve okunabilirliği açısından önemli bir yapı elemanıdır.

\subsubsection{Sığınma ve Barınma İhtiyacı}

İnsan iç mekânda mahremiyet alanlarının korunmasını, kişisel ihtiyaçlarının karşılanmasını ve kendini güvende hissetmeyi ister. Bu nedenle iç mekân tasarımı ortamdan uzaklaşılmadan ama aynı zamanda yalnız kalabilmeye olanak tanımalıdır. Bu amaçla yüksek arkalıklı sandalye, baş üstü kafes gibi modüler, okuma köşeleri, kabin oturma, gölgelikler gibi kısmi ya da okuma/telefon/uyku kabinleri, toplantı odaları gibi kapsamlı sığınaklar tasarlanabilir (Browning ve diğ., 2014, s.46). Buradaki sığınma ve barınma ihtiyacı mekânda hissedilen aidiyet duygusunun güçlendirilmesi olarak açıklanabilir. Kullanıcı mekân ile ne kadar aidiyet kurabilir ise bu deneyimi de o kadar hissedebilir. Hastanenin hasta yatak odaları haricinde birçok bekleme noktasında konumlandırılan dinlenme köşelerinde televizyon izleme, su/çay/kahve/ikram bankoları, çalışma köşeleri, su ve içecek otomatları sığınma ve barınak intiyaçlarını karşılamaktadır. Özellikle mahremiyet duygusu gözetilerek tasarlanmış bireysel dinlenme alanları bu deneyimi güçlü olarak karşılamaktadır (Şekil 16). Ayrıca aidiyet duygusunu güçlendirmek amacı ile koridorlarda oluşturulan sanat galerilerinde hasta çocukların yaptıkları resimlerin ve belli zamanlarda değiştirilen geçici sanat eserlerinin sergilendiği bir köşe bulunmaktadır (Şekil 17).
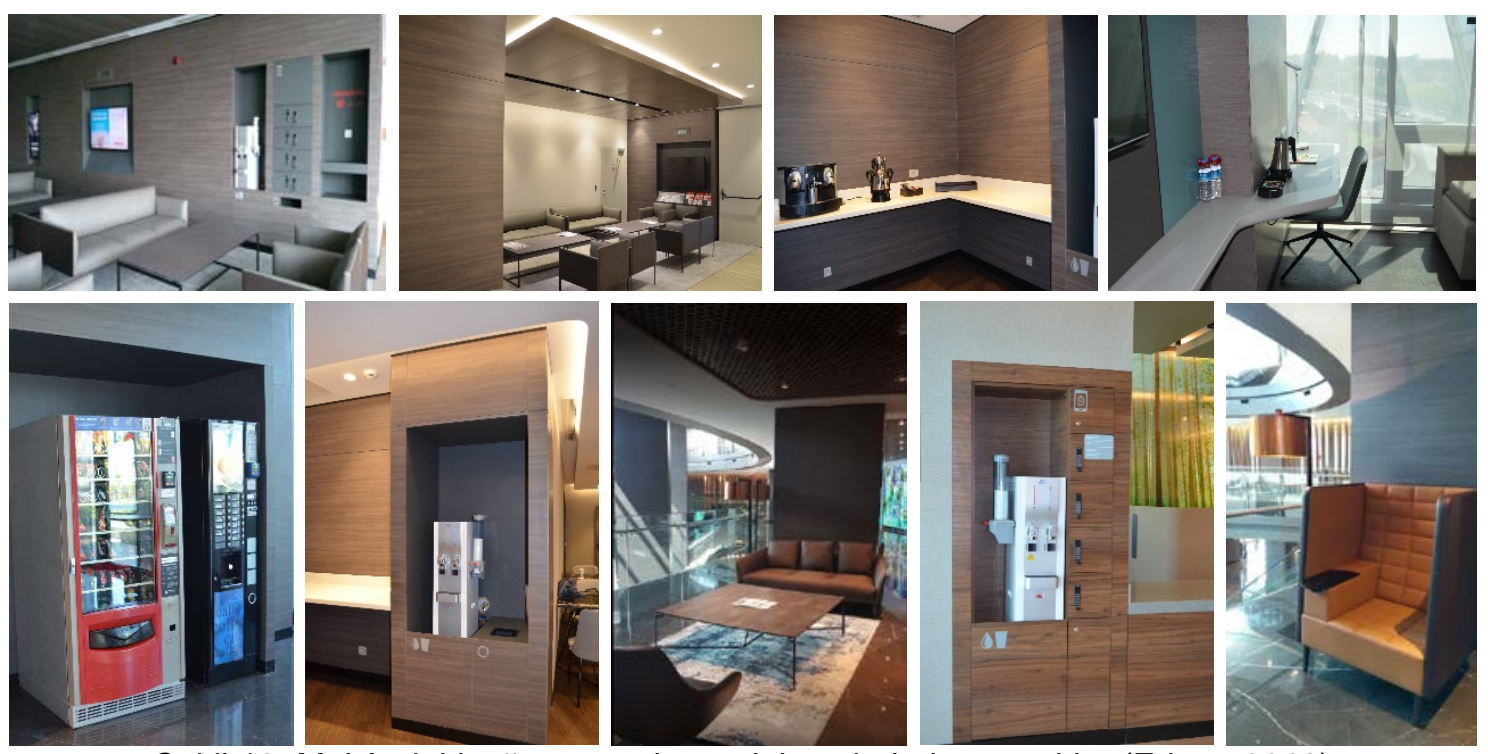

Şekil 16. Mekândaki sığınma ve barınak köşelerinden örnekler (Erbay, 2019) 

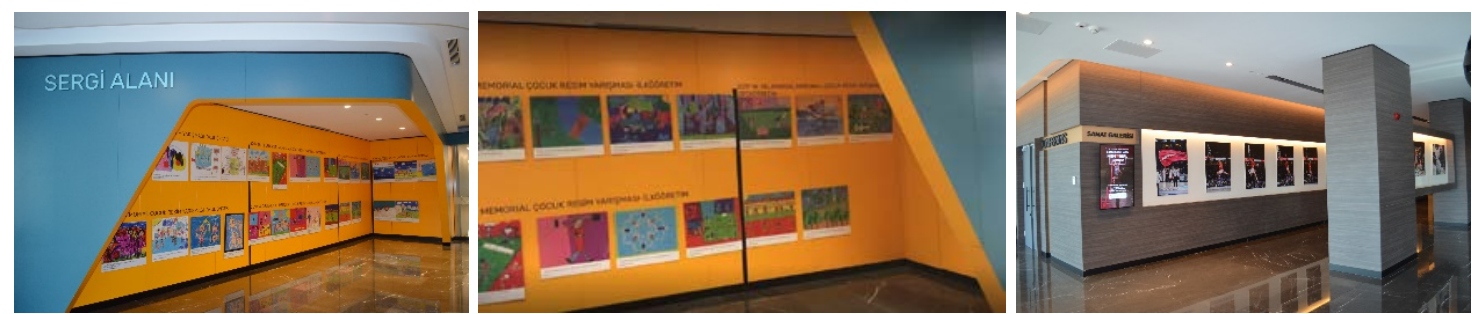

Şekil 17. Sergi köşelerinden örnekler (Erbay, 2019)

\subsubsection{Mekânın Gizemi}

Gizem deneyiminin amacı işlevsel bir ortam sağlarken stresi azaltmayı, bilişsel bir keşfetmeyi teşvik etmesidir. Bu amaçla tasarlanan işitsel ve görsel uyarılar, hem mekanı okumayı kolaylaştırması hem de merak duygusunu uyandırması bakımından önemlidir (Browning ve diğ., 2014, s.48). Koridorlarda ışık gölge oyunları, sanat eserleri, müzik, koku, yarı saydam malzemeler, merak uyandıran sürprizli açıklıklar bu başılık altında değerlendirilmiştir. Giriş salonunda kullanıcının özel bir koku ile karşılaşması, dijital sanat ve biyofilik heykel merak duygusunu da uyandırmaktadır. Bol ışık alan mekânlar günün her saatinde değişen ışık gölge oyunları ile dinamik bir etkiye sahiptir. Ayrıca koridorlardaki sanat eserleri hem sürprizli köşeler yaratmak için hem de yönlendirici ve yön bulmayı kolaylaştırıcı ögeler olarak kullanılmışlardır. Yine bodrum katta yer alan ibadethanelerde mistik etki yaratan dini semboller mekânın gizemi deneyimine hizmet etmektedir (Şekil 18).
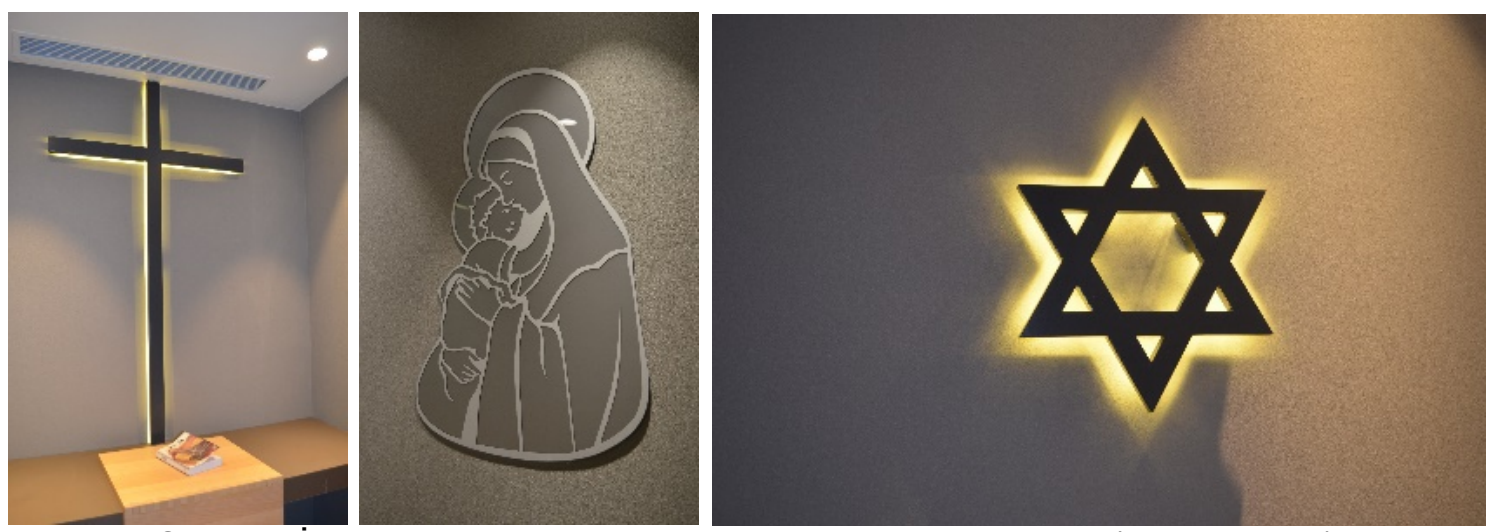

Şekil 18. İbadethanelerde yer alan dini sembollerden örnekler (Ulusoy, 2019)

\subsubsection{Tehlikeler ve Riskler}

Tehlike ve risklerin korku ile arasındaki tanımlayıcı fark, algılanan tehdit ve kontrol seviyesidir. Cepheden dışarı fırlayan konsol bir balkon, alt mekânı gösteren cam döşeme gibi tasarımlar bu başlık altında değerlendirilebilir. Kontrol edilebilir seviyedeki bir tehdit ya da risk bilincine sahip olmak olumlu deneyimleri tetikleyebilir. Bu modelin amacı dikkat ve merak uyandırmak, hafızayı ve problem çözme becerilerini çözmeye teşvik etmektir. Tasarım sürecince kullanıcıyı zarar görmekten koruyucu önlemler, güven duygusu veren konseptler bu deneyimi yaşatmaktadır (Browning ve diğ., 2014, s.50). Hastanenin tasarımı evrensel tasarım ilkeleri ile tasarlandığından çocuk, engelli ve hasta kullanıcı intiyaçları karşılanmaktadır. Yapının okunabilirliği, yönlendirme ve bilgi tabelaları belli noktalarda net bir şekilde okunmaktadır. Bazı noktalarda kullanılan dijital ekranlar bilişsel duyuya hitap etmekte, kullanıcının isteği doğrultusunda kendisi ile iletişime geçmektedir (Şekil 19). Emedya Design'ın yönlendirme ve sanat danışmanlığında tasarlanan bu tabelalar doku ve malzeme olarak hastanenin tasarım konsepti ile uyumludur. Tehlikeler ve riskler doğada karşılandığında adrenalin sağladığı 
için doğal karşılanabilir. Ancak hastane işlevi nedeni ile heyecan yaratacak türde, tehlike ve risk algısı oluşturacak tasarımlara yer verilmemiştir.
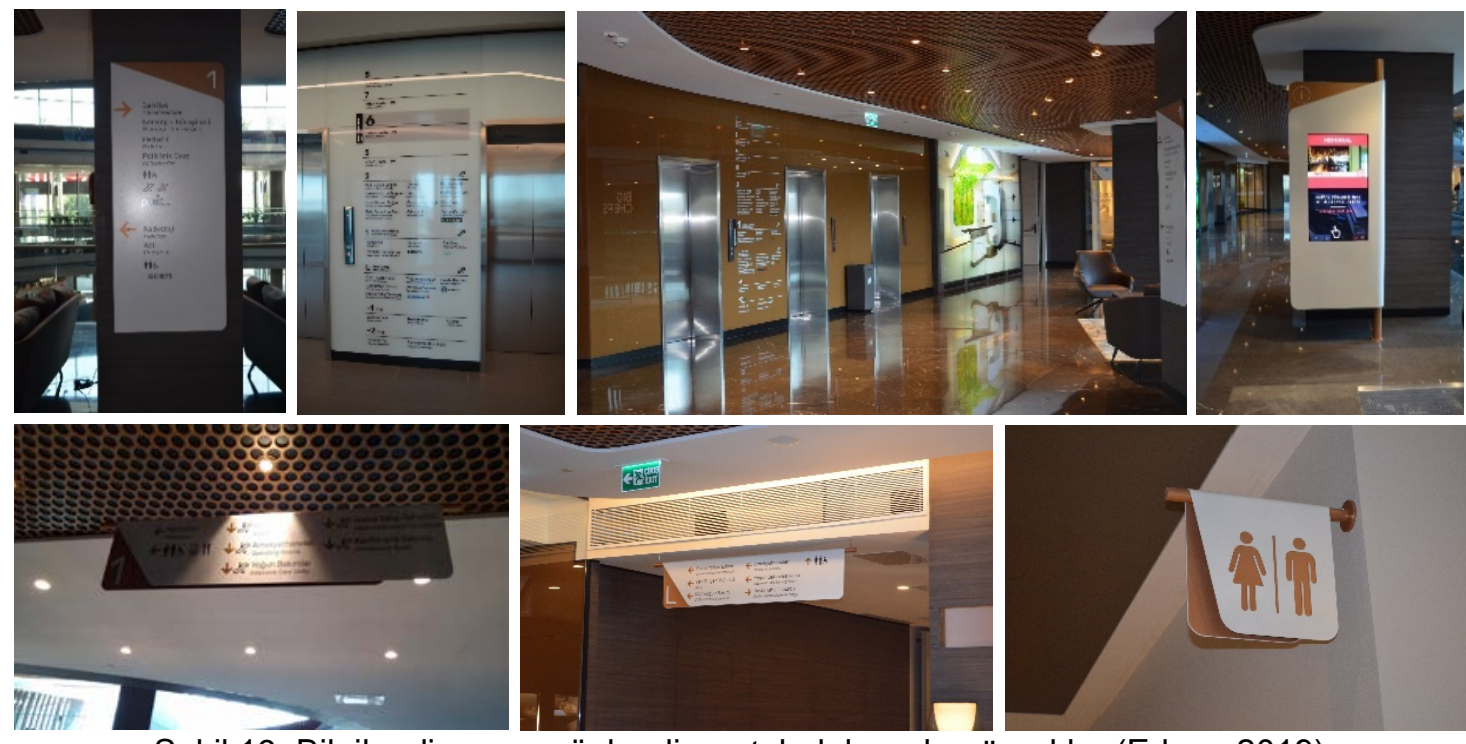

Şekil 19. Bilgilendirme ve yönlendirme tabelalarından örnekler (Erbay, 2019)

\section{Sonuç}

İç mekân tasarımında doğa temelli tasarım modellerinin uygulanmasının temelleri doğaya duyulan özlemin ötesinde, insanın sağlığı ve psikolojisi üzerindeki olumlu etkilerine dayanmaktadır. Sağlık için doğa ile insan yapımı çevreler arasında güçlü bağlantılar oluşturmaya odaklanan biyofilik tasarımın, doğa temelli diğer tasarım modellerinden ayrıştığı en önemli özelliği mekânın kullanıcısına sunduğu deneyimdir. Stres ve endişe duygularını azaltması, bilişsel ve duyusal enerjiyi artırması, doğa ile bağlantı kurması, ekosistemlerle uyumlu olmasının yanı sıra yeşil bina sertifikasyonları için sürdürülebilir bir yaklaşım sunması da en önemli avantajlarından bazılarıdır. Bu anlamda "biyofilik mimari" terimi, bir binanın çevreye uyarlanması ve bu doğrultuda tasarlanması anlamına gelmektedir.

Sağlık yapılarında daha da önem kazanan biyofilik tasarım deneyimlerinin uygulanabilirliği bu çalışma özelinde Memorial Bahçelievler Hastanesi örnekleminde ele alınarak irdelenmiştir. Mekânın içindeki doğa, doğal benzerlikler ve mekânın doğası başlıkları altında verilen bu tasarım deneyimlerinin hastane tasarımına nasıl yansııılı̆̆ı görsellerle de desteklenerek değerlendirilmiştir. İncelenen Browning ve arkadaşlarının (2014) ortaya koyduğu biyofilik tasarımın 14 deneyimini karşılamak için, Memorial Bahçelievler Hastanesi özelinde iç mekân tasarımlarında yapılan uygulamalar Şekil 20 'de verilmiştir. 


\begin{tabular}{|c|c|c|}
\hline Mekândaki Doğa & Doğal Benzerlikler & Mekânın Doğası \\
\hline $\begin{array}{l}\text { 1. Doğa ile görsel bağlantı } \\
\text { - Kat bahçeleri } \\
\text { - Avlular } \\
\text { 2. Doğa ile görsel olmayan bağlantı } \\
\text { - Cam katmanlar arası doğa } \\
\text { görüntüsü } \\
\text { - Gergi tavan uygulamaları } \\
\text { - Doğa resimleri (Tablo/dijital) } \\
\text { - Enstalasyon çalışmaları } \\
\text { 3. Değişken doğal duyusal uyaranlar } \\
\text { - Özel koku tasarımı } \\
\text { - Müzik kullanımı/tasarımı } \\
\text { - Dijital sanat } \\
\text { 4. Termal ve hava akışı } \\
\text { - Açlır pencereler } \\
\text { - Avluya çıkı̧s sağlanması } \\
\text { 5. Suyun varlığı } \\
\text { - Yapay dış mekan süs havuzu } \\
\text { - Yapay iç mekan süs havuzu } \\
\text { - Dijital sanat } \\
\text { 6. Dinamik ve yaygın ışı } \\
\text { - Lineer plan tasarımı } \\
\text { - Geniş pencereler } \\
\text { - Cam tavan } \\
\text { 7. Doğal ekosistemlerle bağlantı } \\
\text { - Sürdürülebilir malzeme } \\
\text { - Doğal malzeme } \\
\text { - Doğal havalandırma } \\
\text { - Kojenerasyon sistemi }\end{array}$ & $\begin{array}{l}\text { 8. Biyomorfik Formlar ve Desenler } \\
\text { - Organik biçimler/formlar } \\
\text { - Tasarımsal dokular } \\
\text { - Malzeme dokuları } \\
\text { - Yüzey tasarımları } \\
\text { 9. Doğa ile Maddi Bağlantılar } \\
\text { - Doğal malzemeler } \\
\text { - Doğal renkler } \\
\text { - Malzeme dokuları } \\
\text { - Doğa resimleri (Tablo/dijital) } \\
\text { - Enstalasyon çalışmaları } \\
\text { 10.Doğada Karşılaşılan Hiyerarşik } \\
\text { Düzen } \\
\text { - Organik biçimler/formlar } \\
\text { - Tasarımsal dokular } \\
\text { - Malzeme dokuları } \\
\text { - Yüzey tasarımları } \\
\text { - Yapay ışık }\end{array}$ & $\begin{array}{l}\text { 11. Mekândan beklentiler } \\
\text { - Geniş mekanlar } \\
\text { - Manzaranın sürekliliği } \\
\text { - Şeffaf ya da yarı şeffaf } \\
\text { duvarlar } \\
\text { - Alçaltılııs duvarlar } \\
\text { - Doğa resimleri (Tablo/dijital) } \\
\text { - Özel koku tasarımı } \\
\text { - Müzik kullanımı/tasarımı } \\
\text { - Enstalasyon çalışmaları } \\
\text { 12. Sığınma ve barınma intiyacı } \\
\text { - Dinlenme/çalışma köşeleri } \\
\text { - Tv izleme/bekleme alanları } \\
\text { - Içecek otomatları } \\
\text { - Ikram bankoları } \\
\text { - Sanat galerileri } \\
\text { 13. Mekânın gizemi } \\
\text { - Işık/gölge } \\
\text { - Doğa resimleri (Tablo/dijital) } \\
\text { - Enstalasyon çalışmaları } \\
\text { - Dijital bilgilendirme } \\
\text { - Semboller/Simgeler } \\
\text { - Koku tasarımı } \\
\text { - Müzik kullanımı/tasarımı } \\
\text { 14. Tehlikeler ve riskler } \\
\text { - Bilgilendirme tabelaları } \\
\text { - Yönlendirme tabelaları } \\
\text { - Dijital bilgilendirme }\end{array}$ \\
\hline
\end{tabular}

Şekil 20. Bahçelievler Memorial Hastanesi biyofilik tasarım uygulamaları (Yazar tarafından oluşturulmuştur)

$\mathrm{Bu}$ uygulamalar değerlendirildiğinde iki başlık altında eksiklikler olduğundan söz edilebilir. Bunlardan ilki; doğal ekosistemlerle bağlantı noktasında güneş enerjisi, rüzgâr enerjisi, yağmur suyunun/atık suların toplanması, arıtıması ya da değerlendirilmesi gibi çalışmaların olmaması, sürdürülebilir malzemelerin kullanımına özen gösterilmesine rağmen kullanılan malzemelerin ve mobilyaların firmalara bağlı olarak sertifikasyonlarının bulunmamasıdır. İkincisi ise tehlike ve riskler başlığıdır. Ancak bir sağlık yapısında hasta ya da hasta yakınları için tehlike ve risklerin mekânda yaratacağı heyecan olumlu karşılanmayacağından bilinçli olarak uygulanmadığı düşünülmektedir.

Biyofilik tasarım deneyimlerinin yansıtılmasına yönelik iç mekân uygulamalarına bakıldığında kullanıcı üzerinde yarattığı fizyolojik ve psikolojik etkilerin bir takım uyaranlar sayesinde sağlandığı görülmektedir. Bu açıdan değerlendirildiğinde iç mekânda biyofilik tasarım deneyimlerini harekete geçiren uyaranlar doğal, fiziksel ve duyusal olarak sınıflanabilir. Bu uyaranların hastane iç mekânında biyofilik tasarım deneyimleri/ilkeleri ile ilişkisi iseTablo1'de verilmiştir. 
İç Mekânda Biyofilik Tasarım ve Uygulama Alanı Olarak Bir Sağlık Yapısı: Memorial Bahçelievler Hastanesi A Healthcare Structure as A Biophilic Design and Application Area in The Interior: Memorial Bahçelievler Hospital

Tablo 1. İç mekânda biyofilik tasarım deneyimlerinin/ilkelerinin doğal, fiziksel ve duyusal uyaranlarla ilişkisi (Yazar tarafından oluşturulmuştur)

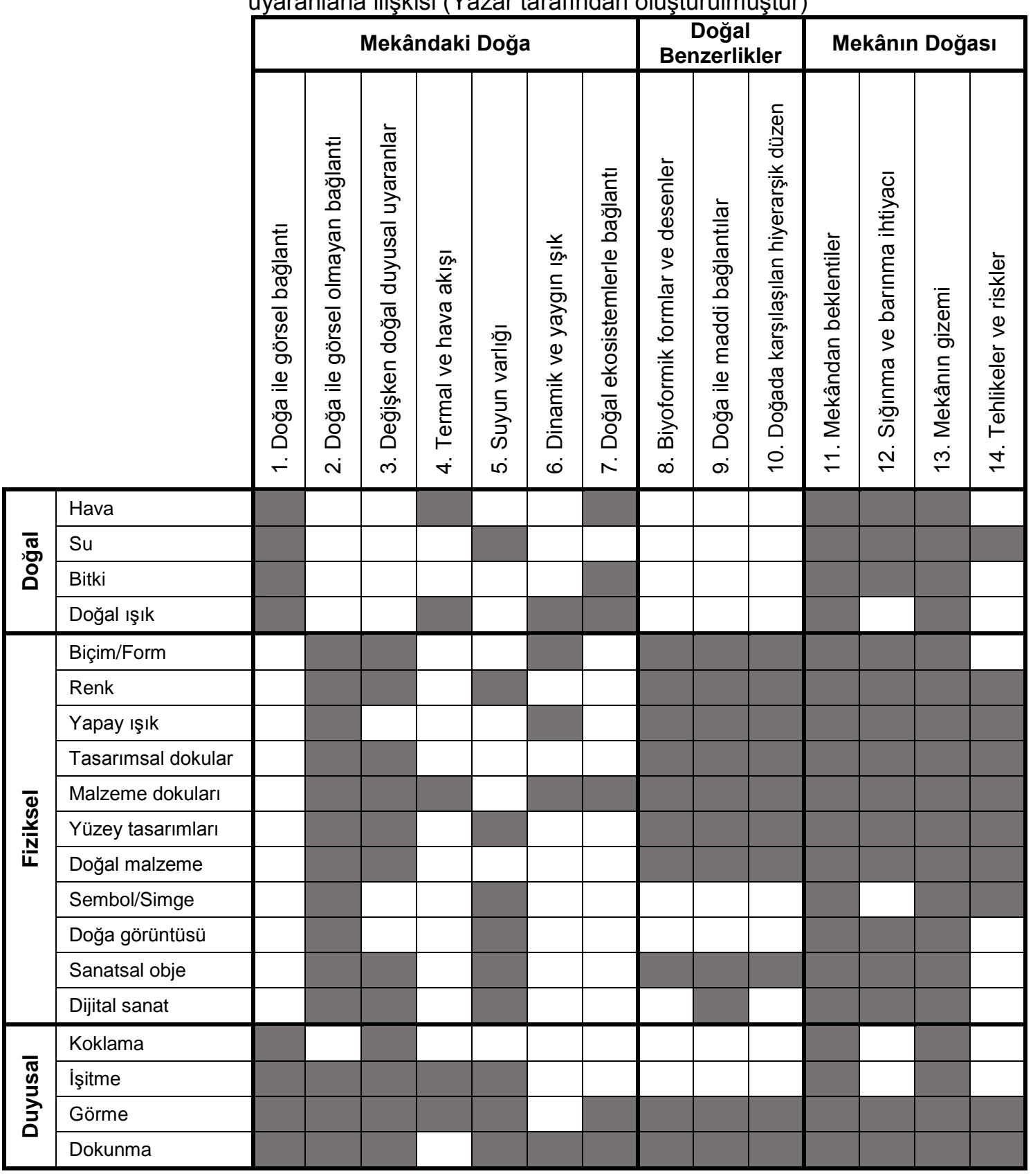

Tabloda doğal, fiziksel ve duyusal uyaranlara yönelik iç mekândaki tasarım ilkelerinin deneyimlerle yoğun ilişkisi olduğu görülmektedir. Doğal uyaranlar, doğa ile görsel bağlantıyı kurması açısından mekândaki doğanın hissedilmesine ve mekânın doğasının deneyimlenmesine katkı sağlamaktadır. Her iç mekân tasarımında özenle tasarlanması gereken biçim/form, renk, yapay ışık, tasarımsal dokular, malzeme dokuları, yüzey tasarımlarına ek olarak doğal malzeme, sembol/simge, doğa görüntüsü içeren resim sanatı, dijital sanat ve enstalasyon çalışmalarının kullanılması fiziksel uyaran olarak biyofilik tasarım ilkelerinin deneyimlenmesine yardımcı olmaktadır. Duyusal uyaranların ise dinamik ve yaygın ışık ile doğal ekosistemlerle bağlantı deneyimi dışında diğer deneyimlerin üzerindeki yoğun etkisi de göz ardı edilmemesi gereken önemli bir noktadır. 
Sonuç olarak;

- Çalışma boyunca görsellerle ortaya konmaya çalışılan değerlendirmeler,

- Biyofilik tasarımın iç mekânda uygulaması noktasında fikir vermesi açısından neler yapılabileceğini gösteren Şekil 20,

- İç mekânda biyofilik tasarım deneyimlerinin/ilkelerinin doğal, fiziksel ve duyusal uyaranlarla ilişkisini aktaran Tablo 1 ,

doğrultusunda, incelenen Memorial Bahçelievler Hastanesi'nin biyofilik tasarım deneyimlerini karşıladığı ve sağlık yapıları için bir örnek teşkil ettiği söylenebilir.

Çalışmanın genel sonucu olarak da; biyofilik tasarım deneyimlerinin iç mekânda uygulanabilmesi için genel tasarım ilkelerine ek olarak hava, su, bitki, doğal ışık gibi doğal, doğayı çağrıştıran her türlü biçim/form, malzeme, renk, yüzey, doku, obje, sanat ve enstalasyon çalışmaları gibi fiziksel, koklama, işitme, görme ve dokunma gibi duyusal uyarıları da harekete geçiren tasarımlar yapılması gerektiği söylenebilir. Yani biyofilik tasarımdan söz edebilmek için sadece yeşilin doğal ya da yapay kullanımı yeterli görülmemekte, doğal, fiziksel ve duyusal uyaranlarla mekânın deneyimlenmesi gerekmektedir. İnsanın da doğanın parçası olduğu kabulünden hareketle doğal çevrenin yararları ve onarıcı etkisine daha geniş bir perspektiften bakmak ve anlamak önemlidir. Doğanın iç mekâna entegrasyonunu sağlayan biyofilik tasarım deneyimleri hem insanların doğa ile bağlantı kurma ihtiyacı karşılanmakta hem de doğanın yapılı çevre içindeki iyileştirici gücünü artırmaktadır. Stresin ve zihinsel yorgunluğun iyileşmesine yardımcı olduğu birçok çalışma ile ortaya konan bu tasarım deneyimlerinin sadece sağlık yapılarında değil, tüm yapılı çevrelerde iç mekâna uygulanması, sağlıklı nesillerin devamlılığı ve iş veriminin artırılması için bir yol olabilir. Özellikle eğitim ve ofis yapıları başta olmak üzere mevcut mekânlarda yeni düzenlemeler ile bu bağlantılar sağlanabileceği gibi, tasarım aşamasında da bir model olarak uygulanabilir. Unutmamak gerekir ki günümüzde yapılı çevre içinde doğa ile insan ilişkisini güçlendiren tasarımlar bir lüks değil, bir gerekliliktir. Biyofilik tasarımın özünde de doğa ile bağlantının güçlendirilmesinden ziyade doğa ile var olan bağın eski haline getirilmesi yatmaktadır.

\section{Kaynaklar}

Akrami, Behnaz, The Evaluation of Awareness and Implementatıon of Biophilic Design Patterns in Healthcare Environments: Case Study The Pars Hospital in Iran, M.Sc. Thesıs, Istanbul Technıcal Unıversıty, Graduate School Of Scıence Engıneerıng And Technology, İstanbul 2017.

Al-Rhodesly, Ahmed, Al Hagla, Khalid,Farghaly, Tarek, ve El-Gamal, Mohammed, "Revisiting the Alhambra Architecture: Biophilic Design Approach", Proceedings of the 6th International Conference on Heritage and Sustainable Development, Volume: 1, Green Lines Institute, Granada/Spain 2018, 373-386.

Anonim, Joint Commission International Hastaneler İçin Akreditasyon Standartları, Joint Commission Resources, Inc., ABD, 2014,

https://www.jcrinc.com/-/media/deprecated-unorganized/imported-assets/jcr/defaultfolders/items/ebjcih14t_sample_pagespdf.pdf?db=web\&hash=5ABBC86015D590195F 069DBC180A1878 adresinden alındı. (Erişim Tarihi: 08.12.2020)

Anonim, Sağlıkta Kalite Standartları Hastane, 2020, Sağlık Bakanlığı Yayın No: 1156, Ankara, 2020, 
İç Mekânda Biyofilik Tasarım ve Uygulama Alanı Olarak Bir Sağlık Yapısı: Memorial Bahçelievler Hastanesi

https://kalite.saglik.gov.tr/Eklenti/38654/0/skshastanesetiv62020revize29082020pdflink pdf.pdf adresinden alındı. (Erişim Tarihi: 04.01.2021)

Baran Toz, Fulden, Kişisel Fotoğraf Arşivi, 2021.

Beatley, Timothy, "Biophilic Cities: What Are They?". Biophilic Cities, Island Press, Washington DC. 2011, 45-81.

Browning, William, Ryan, Catherine ve Clancy, Joseph, 14 patterns of biophilic design Improving Health \& Well-Being in the Built Environment, Terrapin Bright Green LLC, New York NY | Washington DC 2014, https://www.terrapinbrightgreen.com/reports/14patterns/ adresinden alındı. (Erişim Tarihi: 16.08.2021)

Connellan, Kathleen, Gaardboe, Mads, Riggs, Damien, Due, Clemence, Reinschmidt, Amanda ve Mustillo, Lauren, "Stressed Spaces: Mental Health and Architecture", Health Environments Research \& Design Journal (HERD), Vol. 6, No. 4, Vendome Group LLC, Summer 2013, 127-168.

Çorakçı, Rengin Ege, İç Mimarlıkta Biyofilik Tasarım Illkelerinin Belirlenmesi, Doktora Tezi, Mimar Sinan Güzel Sanatlar Üniversitesi Fen Bilimleri Enstitüsü, İstanbul 2016.

Derr, Victoria ve Lance, Krista, "Biophilic Boulder: Children's Environments That Foster Connections to Nature", Children, Youth and Environments 22(2), 2012, 112-143.

Downton, Paul, Jones, David, Zeunert, Josh ve Roös, Phillip "Biophilic Design Applications: Putting Theory and Patterns into Built Environment Practice", The International Conference on Design and Technology, KEG, 2017, 59-65.

Düzenli, Tuğba, Tarakçı Eren, Emine ve Akyol, Duygu, "Peyzaj Mimarlığında Sürdürülebilirlik ve Biyofilik Tasarım Kavramı", Akademik Sosyal Araştırmalar Dergisi, Yıl: 5, Sayı: 48, Haziran 2017, 43-49.

Erbay, Muteber, Kişisel Fotoğraf Arşivi, 2019.

Fischl, Géza, Biophilic Living A Behavior Responsive Architecture, Independent thesis Advanced level, Umeå University, Faculty of Science and Technology, Umeå School of Architecture, 2016.

Fromm, Erich, On Being Human, The Continuum International Publishing Group Ltd., New York 2005.

Gillis, Kaitlyn ve Gatersleben, Birgitta, "A Review of Psychological Literature on the Health and Wellbeing Benefits of Biophilic Design", Buildings 5 (3), 2015, 948-963.

Gray, Tonia, "Retrofitting Biophilic Design Elements into Office Site Sheds: Does 'Going Green' Enhance the Well-Being and Productivity of Workers?", Landscape Architecture - The Sense of Places, Models and Applications, Ed: Amjad Almusaed, IntechOpen, September 2018, 105-126.

Gullikson, Christina L., Human Connection to Nature Within the Built Environment: An Exploration of Office Employee Perception of Nature Connectedness, Electronic Theses, Treatises and Dissertations, The Florida State University, 2011, 
http://purl.flvc.org/fsu/fd/FSU_migr_etd-3919 adresinden alındı. (Erişim Tarihi: 17.02.2021)

Gullone, Eleonora, "The Biophilia Hypothesis and Life in the 21st Century: Increasing Mental Health or Increasing Pathology?", Journal of Happiness Studies 1(3), September 2000, 293-322.

Habibi, Saeid ve Akrami, Behnaz, "Applicable Biophilic principles on hospitals retrofitting. The case study of Turkish Public Hospitals", Poster Sunumu, Conference: ANFA 2018 Conference, California 2018,

https://www.researchgate.net/publication/327231119_Applicable_Biophilic_principles_o n_hospitals_retrofitting_The_case_study_of_Turkish_public_hospitals September 2018 adresinden alındı. (Erişim Tarihi: $1 \overline{7} .02 .202 \overline{1})$

Hartig, Terry, Ewans, Gary, W., Jammer, Larry D., Davis, Deborah S. ve Garling, Tommy, "Tracking Restoration in Natural and Urban Field Settings," Journal of Environmental Psychology, Cilt: 23, Sayı:2, 2003, 109-123.

Hidalgo, Ana Karinna, "Biophilic Design, Restorative Environments and Well-Being", Proceedings of the Colors of Care: The 9th International Conference on Design \& Emotion, Eds: Salamanca, J., Desmet, P., Burbano, A., Ludden, G., Maya, J., Ediciones Uniandes, Bogotá, October 6-10, 2014, 535-544.

Hudson, Katelyn PC, Holistic Dwelling: Integrating Biophilic Design, Environmental Psychology, and Feng Shui, Thesis for: Doctorate of Architecture, School of Architecture University of Hawai, May 2013.

Kellert, Stephen Robert ve Wilson, Edward O., The Biophilia Hypothesis, Island Press, Washington, DC. 1993.

Kellert, Stephen Robert, "Dimension, Elements, and Attributer of Biophilic Design", Biophilic Design: The Theory, Sicience and Practice of Bringing, Eds: Stephen R. Kellert, Judith $\mathrm{H}$. Heerwagen ve Martin L. Mador, John Wiley\&Sons, Inc, NJ Hoboken 2008, 3-19.

Kellert, Stephen Robert ve Calabrese, Elizabeth F., The Practice of Biophilic Design, 2015, www.biophilic-design.com adresinden alındı. (Erişim Tarihi: 10.08.2020)

Kellert, Stephen Robert, "Building for Life: Designing and Understanding the HumanNature Connection", Renewable Resources Journal, Summer 2006, 8-24.

Krčmářová, Jana, "Wilson's concept of biophilia and the environmental movement in the USA", Klaudyán: Internet Journal of Historical Geography and Environmental History, Volume 6, No.1-2, 2009, 4-17.

Leakas, Diana, Biophilia in Designing, A Thesis Submitted to the Division of Research and Advanced Studies of the University of Cincinnati, 2008.

Messelmani, Aya El, Biophilia, Humans \& the Connections, A Thesıs Submitted to the Department of Architecture for the Masters of Arts in Architecture Degree, Department of Architecture The Unıversity Of Nicosia, Cyprus 2018. 
Mustafa, Faris Ali ve Yaseen, Fatin Radwan, "Towards The Applıcatıon of Bıophılıc Parameters in Local Buıldıngs: A Case Study of Bilkent School, Erbil City-Iraq", International Journal Of Technology 10(2), Indonesia 2019, 363-375.

Ojamaa, Heli, Enhancing The Human-Nature Connection Through Biophilic Design In the Built Environment: A Branch Library on the Banks of Lake Union, A Thesis Submitted in Partial Fulfillment of the Requirements for the Degree of Master of Architecture University of Washington, 2015.

Onuk, Tuğçe, Eşbah, Hayriye, Erbaş Gürler, Ebru ve Çiçek, İrem, 2015. "Experimenting Landscape Scale Biophilic Design: Case of Konyaaltı, Antalya, Turkey", Eclas 2015 Conference Landscapes In Flux, Eds: Gloria Niin ve Himansu Sekhar Mishro, Estonya 2015, 550-559.

Pranita, Pranjale ve Hejiib, Deepali K., "Biophillic Design -A sustainable Approach", Eco Design: Design With Nature, National Conference NCBTW, Volume 1, Issue:1, 2019, https://www.researchgate.net/publication/340161940_Biophilic_Design_A_Sustainable_Approach adresinden alındı. (Erişim Tarihi: 12.08.2020)

Ramzy, Nelly Shafik, "Biophilic Qualities of Historical Architecture: in Quest of the Timeless Terminologies of 'Life' in Architectural Expression", Sustainable Cities and Society $15,2015,42-56$.

Russo, Alessıo ve Cirella, Gıuseppe T., "Biophilic Cities: Planning for Sustainable and Smart Urban Environments", Smart Cities Movement in BRICS, Ed: Rumi Aijaz, Observer Research Foundation and Global Policy Journal, New Delhi 2017, 153-159.

Scharoun, Lisa ve Montana, Carlos, "Nature in Repurposed Post-Industrial Environments", The International Journal Of Architectonıc, Spatial, And Environmental Design, Volume:6, Issue:3, Common Ground Publishing LLC, Illinois USA 2013, 25-35.

Şenozan, M. Işıl, Insan - Mekân - Doğa Etkileşiminin Sürdürülebilir Bir Öğretisi Olarak Biyofilik Tasarım, Mimar Sinan Güzel Sanatlar Üniversitesi Fen Bilimleri Enstitüsü, 2018.

Totaforti, Simona, "Applying the Benefits of Biophilic Theory to Hospital Design" City Territory Architecture 5:1, Italya 2018, 2-9.

Ulrich, Roger S., "Biophilic Theory and Research for Healthcare Design", Biophilic Design: The Theory, Sicience and Practice of Bringing, Eds: Stephen R. Kellert, Judith H. Heerwagen ve Martin L. Mador, John Wiley\&Sons, Inc, NJ Hoboken 2008, 87-106.

Ulrich, Roger S., Zimring, Craig, DuBose, Jennifer, Seo, Hyun-Bo, Choi, Young-Seon, Quan, Xiaobo ve Joseph, Anjali, "A Review of the Research Literature on EvidenceBased Healthcare Design", Health Environments Research \& Design Journal (HERD), Vol. 1, No. 3, Vendome Group LLC, Spring 2008, 101-165.

Ulusoy, Serenay, "Üst Yüzey Kaplamaları Özelinde İç Mekân Yapısal Detayları Üzerine Bir Sınıflandırma Önerisi”, Yüksek Lisans Tezi, KTU Fen Bilimleri Enstitüsü, 2021.

Ulusoy, Serenay, Kişisel Fotoğraf Arşivi, 2019. 
Wilson, Edward O., Biophilia, (Ilk Basım:1984), 12. Basım, Harward University Press, USA 2003.

Yüksel, Heval Zeliha, "Memorial Bahçelievler Hastanesi Zoom / TPU Mimarlık" Natura, Temmuz-Ağustos 2018, 100-107.

Zari, Maibritt Pedersen, "Understanding and Designing Nature Experiences in Cities: A Framework for Biophilic Urbanism", Cities \& Health, Volume:3, Issue:1-2, 2019, 1-12, https://www.academia.edu/43122285/Understanding_and_designing_nature_experienc es_in_cities_a_framework_for_biophilic_urbanism adresinden alındı. (Erişim Tarihi: 21.08.2020)

Zumthor, Peter, Thinking Architecture, Birkhauser - Publishers for Architecture, Basel . Boston · Berlin 1998.

URL-1: $\quad$ https://www.ekoyapidergisi.org/4282-memorial-saglik-grubu-leed-platinumsertifikasini-aldi.html, Memorial Sağlık Grubu LEED Platinum Sertifikasını Aldı, Erişim Tarihi: 20.02.2021.

URL-2: $\quad$ http://www.zoom.com.tr/tr/projects/memorial-hospital-bahcelievler, Projeler/Memorial Hastanesi/ Bahçelievler, Erişim Tarihi: 20.02.2021.

URL-3: $\quad$ http://www.arkiv.com.tr/proje/memorial-bahcelievler-hastanesi-ic-mekantasarimi/9740, Memorial Bahçelievler Hastanesi İç Mekân Tasarımı Erişim Tarihi: 18.02.2021.

URL-4: $\quad$ https://www.memorial.com.tr/hastaneler-ve-tip-merkezleri/memorialbahcelievler-hastanesi, Memorial Bahçelievler Hastanesi, Erişim Tarihi: 20.01.2021.

URL-5: $\quad$ https://www.endeksa.com/tr/analiz/istanbul/bahcelievler/demografi, Bahçelievler Nüfus Dağılımı, Erişim Tarihi: 12.01.2021.

URL-6: https://www.audubon.org/birds-of-america, John J. Audubon's Birds of America, Erişim Tarihi: 07.03.2021.

URL-7: https://tr.akdo.com/tr/haber-detay/mermer-bahce-biyofilik-tasarim, Mermer Bahçe: Biyofilik Tasarım, Erişim Tarihi: 07.03.2021.

URL-8: https://nohlab.com/work/abi-hayat, Ab-ı Hayat, Erişim Tarihi: 12.01.2021. 